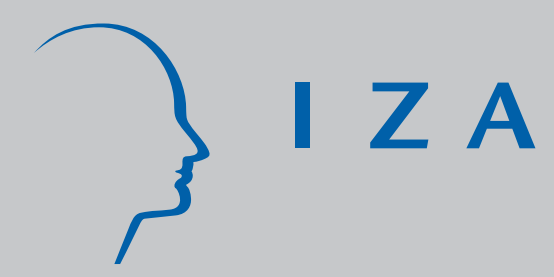

IZA DP No. 1431

The Size of the Shadow Economies of 145 Countries all over the World:

First Results over the Period 1999 to 2003

Friedrich Schneider

December 2004 


\title{
The Size of the Shadow Economies of 145 Countries all over the World: First Results over the Period 1999 to 2003
}

\author{
Friedrich Schneider \\ University of Linz \\ and IZA Bonn
}

\section{Discussion Paper No. 1431 \\ December 2004}

\author{
IZA \\ P.O. Box 7240 \\ 53072 Bonn \\ Germany \\ Phone: +49-228-3894-0 \\ Fax: +49-228-3894-180 \\ Email: iza@iza.org
}

\begin{abstract}
Any opinions expressed here are those of the author(s) and not those of the institute. Research disseminated by IZA may include views on policy, but the institute itself takes no institutional policy positions.

The Institute for the Study of Labor (IZA) in Bonn is a local and virtual international research center and a place of communication between science, politics and business. IZA is an independent nonprofit company supported by Deutsche Post World Net. The center is associated with the University of Bonn and offers a stimulating research environment through its research networks, research support, and visitors and doctoral programs. IZA engages in (i) original and internationally competitive research in all fields of labor economics, (ii) development of policy concepts, and (iii) dissemination of research results and concepts to the interested public.
\end{abstract}

IZA Discussion Papers often represent preliminary work and are circulated to encourage discussion. Citation of such a paper should account for its provisional character. A revised version may be available directly from the author. 
IZA Discussion Paper No. 1431

December 2004

\section{ABSTRACT}

\section{The Size of the Shadow Economies of 145 Countries all over the World: First Results over the Period 1999 to 2003}

Using the DYMIMIC approach, estimates of the shadow economy in 145 developing, transition, developed OECD countries, South Pacific islands and still communist countries are presented. The average size of the shadow economy (in percent of official GDP) over $2002 / 2003$ in developing countries is $39.1 \%$, in transition countries $40.1 \%$, in OECD countries $16.3 \%$, South Pacific islands $33.4 \%$ and 4 remaining Communist countries $21.8 \%$. An increasing burden of taxation, high unemployment and low official GDP growth are the driving forces of the shadow economy.

JEL Classification: $\quad$ O17, O5, D78, H2, H11, H26

Keywords: shadow economy, tax burden, government regulation, DYMIMIC method

Friedrich Schneider

Department of Economics

University of Linz

4040 Linz-Auhof

Austria

Email: friedrich.schneider@jku.at 


\section{Contents}

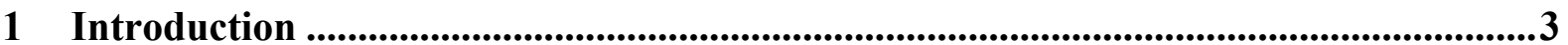

2 Some Theoretical Considerations about the Shadow Economy ...................................4

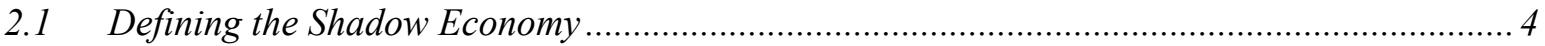

2.2 The Main Causes of Determining the Shadow Economy ...................................................... 6

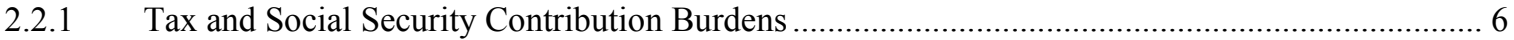

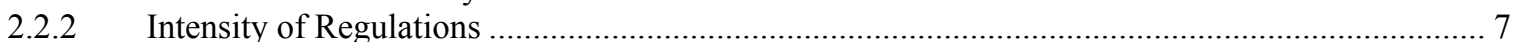

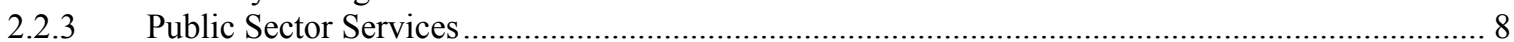

3 The Size of the Shadow Economies all over the World-Findings for 145 Countries.9

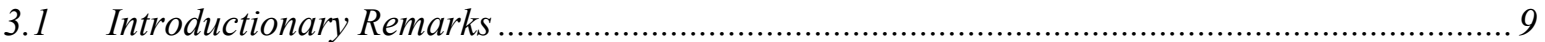

3.2 The Size of the Shadow Economies for 145 Countries for 1999/2000, 2001/2002 and

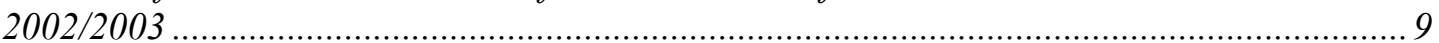

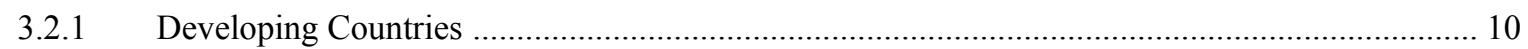

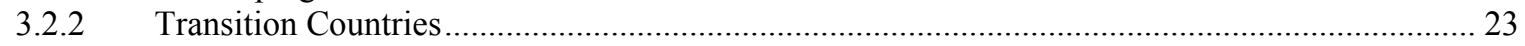

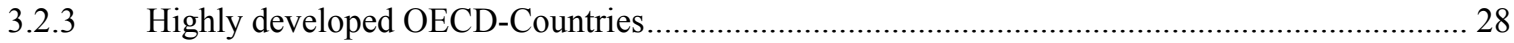

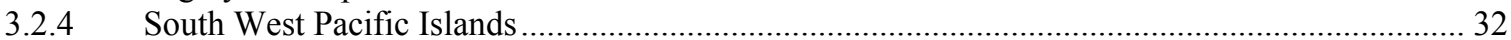

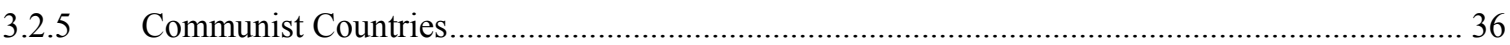

4 Summary and Conclusions ...........................................................................................40

5 Appendix: Methods to Estimate the Size of the Shadow Economy ...........................42

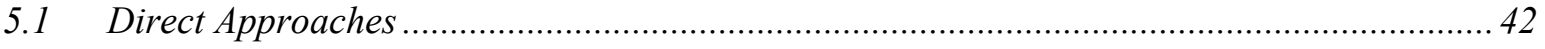

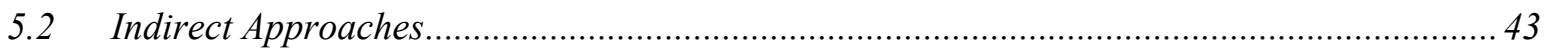

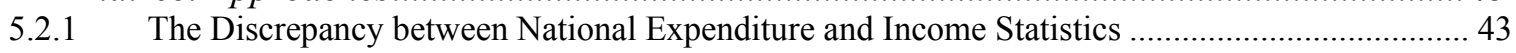

5.2.2 The Discrepancy between the Official and Actual Labor Force .................................................... 44

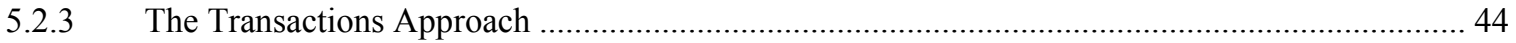

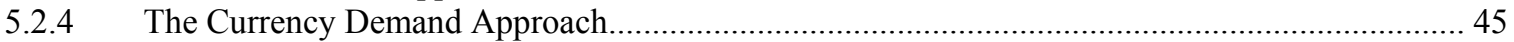

5.2.5 The Physical Input (Electricity Consumption) Method................................................................ 48

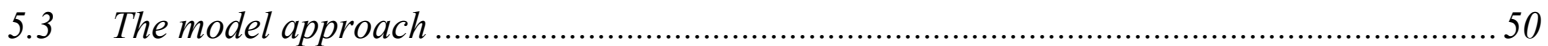

5.4 The Size and Development of the Shadow Economies of 145 Countries over 1999/2000 to

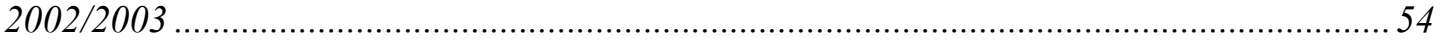

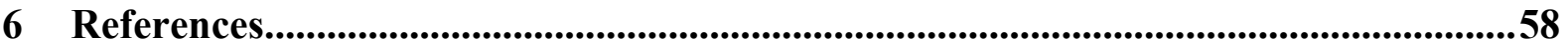




\section{Introduction}

As shadow economic activities are a fact of life around the world, most societies attempt to control these activities through various measures like punishment, prosecution, economic growth or education. Gathering statistics about who is engaged in shadow economy activities, the frequencies with which these activities are occurring and the magnitude of them, is crucial for making effective and efficient decisions regarding the allocations of a country's resources in this area. Unfortunately, it is very difficult to get accurate information about these shadow economy activities on the goods and labor market, because all individuals engaged in these activities wish not to be identified. Hence, the estimation of the shadow economy activities can be considered as a scientific passion for knowing the unknown.

Although quite a large literature ${ }^{1)}$ on single aspects of the hidden or shadow economy exists and a comprehensive survey has been written by Schneider (the author of this paper) and Enste (2000), the subject is still quite controversial ${ }^{2)}$ as there are disagreements about the definition of shadow economy activities, the estimation procedures and the use of their estimates in economic analysis and policy aspects. ${ }^{3)}$ Nevertheless around the world, there are some indications for an increase of the shadow economy but little is known about the development and the size of the shadow economies in transition, development and developed countries over the latest period 1999/2000 to 2002/2003.

Hence, the goal of this paper is twofold: to undertake the challenging task to estimate the shadow economy for 145 countries all over the world and to provide some insights about the main causes of the shadow economy. In section 2 an attempt is made to define the shadow economy and some theoretical considerations about the reasons why the shadow is increasing are undertaken. Section 3 presents the empirical results of the size of the shadow economy over 145 countries all over the world. In section 4 a summary is given and some policy

\footnotetext{
1) The literature about the „shadow“, „underground“, „informal“, ,second“, “cash-“ or „,parallel“, economy is increasing. Various topics, on how to measure it, its causes, its effect on the official economy are analyzed. See for example, survey type publications by Frey and Pommerehne (1984); Thomas (1992); Loayza (1996); Pozo (1996); Lippert and Walker (1997); Schneider (1994a, 1994b, 1997, 1998a); Johnson, Kaufmann, and Shleifer (1997), Johnson, Kaufmann and Zoido-Lobatón (1998a, 1998b); Belev (2003); Gerxhani (2003) and Pedersen (2003). For an overall survey of the global evidence of the size of the shadow economy see Schneider and Enste (2000, 2002), Schneider (2003, 2005) and Alm, Martinez and Schneider (2004).

2) Compare e.g. in the Economic Journal, vol. 109, no. 456, June 1999 the feature "controversy: on the hidden economy".

3) Compare the different opinions of Tanzi (1999), Thomas (1999), Giles (1999a,b) and Pedersen (2003).
} 
conclusions are drawn. Finally in the appendix (chapter 5) the various methods to estimate the shadow economy are presented and critically evaluated.

\section{Some Theoretical Considerations about the Shadow Economy}

\subsection{Defining the Shadow Economy}

Most authors trying to measure the shadow economy face the difficulty of how to define it. One commonly used working definition is all currently unregistered economic activities that contribute to the officially calculated (or observed) Gross National Product. ${ }^{4)}$ Smith (1994, p. 18) defines it as ,market-based production of goods and services, whether legal or illegal that escapes detection in the official estimates of GDP." Or to put it in another way, one of the broadest definitions of it, includes..."those economic activities and the income derived from them that circumvent or other wise government regulation, taxation or observation". ${ }^{5)}$ As these definitions still leave open a lot of questions, table 2.1 is helpful for developing a better feeling for what could be a reasonable consensus definition of the underground (or shadow) economy.

From table 2.1, it becomes clear that a broad definition of the shadow economy includes unreported income from the production of legal goods and services, either from monetary or barter transactions - and so includes all economic activities that would generally be taxable were they reported to the state (tax) authorities. In this paper the following more narrow definition of the shadow economy is used: ${ }^{6)}$ The shadow economy includes all market-based legal production of goods and services that are deliberately concealed from public authorities for the following reasons:

(1) to avoid payment of income, value added or other taxes,

(2) to avoid payment of social security contributions,

\footnotetext{
4) This definition is used for example, by Feige $(1989,1994)$, Schneider $(1994 a, 2003,2005)$ and Frey and Pommerehne (1984). Do-it-yourself activities are not included. For estimates of the shadow economy and the doit-yourself activities for Germany see Karmann $(1986,1990)$.

5) This definition is taken from Del'Anno (2003), Del'Anno and Schneider (2004) and Feige (1989); see also Thomas (1999), Fleming, Roman and Farrell (2000).

${ }^{6}$ Compare also the excellent discussion of the definition of the shadow economy in Pedersen (2003, pp.13-19),
} 
(3) to avoid having to meet certain legal labor market standards, such as minimum wages, maximum working hours, safety standards, etc., and

(4) to avoid complying with certain administrative procedures, such as completing statistical questionnaires or other administrative forms.

Hence, in this paper, I will not deal with typical underground, economic (classical crime) activities, which are all illegal actions that fits the characteristics of classical crimes like burglary, robbery, drug dealing, etc. I also include not the informal household economy which consists of all household services and production. Also this paper does not focus on tax evasion or tax compliance, because it would get to long, and moreover tax evasion is a different subject, where already a lot of research has been underway. ${ }^{7)}$

Table 2.1: A Taxonomy of Types of Underground Economic Activities ${ }^{1)}$

\begin{tabular}{|c|c|c|c|c|}
\hline Type of Activity & \multicolumn{2}{|c|}{ Monetary Transactions } & \multicolumn{2}{|c|}{ Non Monetary Transactions } \\
\hline \multirow[t]{2}{*}{$\begin{array}{l}\text { Illegal } \\
\text { Activities }\end{array}$} & \multicolumn{2}{|c|}{$\begin{array}{l}\text { Trade with stolen goods; drug dealing } \\
\text { and manufacturing; prostitution; } \\
\text { gambling; smuggling; fraud; etc. }\end{array}$} & \multicolumn{2}{|c|}{$\begin{array}{l}\text { Barter of drugs, stolen goods, } \\
\text { smuggling etc. Produce or growing } \\
\text { drugs for own use. Theft for own } \\
\text { use. }\end{array}$} \\
\hline & Tax Evasion & $\begin{array}{l}\text { Tax } \\
\text { Avoidance }\end{array}$ & Tax Evasion & Tax Avoidance \\
\hline $\begin{array}{l}\text { Legal } \\
\text { Activities }\end{array}$ & $\begin{array}{l}\text { Unreported income } \\
\text { from self- } \\
\text { employment; Wages, } \\
\text { salaries and assets } \\
\text { from unreported work } \\
\text { related to legal } \\
\text { services and goods }\end{array}$ & $\begin{array}{l}\text { Employee } \\
\text { discounts, } \\
\text { fringe benefits }\end{array}$ & $\begin{array}{l}\text { Barter of legal } \\
\text { services and } \\
\text { goods }\end{array}$ & $\begin{array}{l}\text { All do-it-yourself } \\
\text { work and } \\
\text { neighbor help }\end{array}$ \\
\hline
\end{tabular}

${ }^{1)}$ Structure of the table is taken from Lippert and Walker (1997, p. 5) with additional remarks.

who uses a similar one.

7) Compare, e.g. the survey of Andreoni, Erard and Feinstein (1998) and the paper by Kirchler, Maciejovsky and Schneider (2002). 


\subsection{The Main Causes of Determining the Shadow Economy}

\subsubsection{Tax and Social Security Contribution Burdens}

In almost all studies ${ }^{8)}$ it has been found out, that the tax and social security contribution burdens are one of the main causes for the existence of the shadow economy. Since taxes affect labor-leisure choices, and also stimulate labor supply in the shadow economy, the distortion of the overall tax burden is a major concern of economists. The bigger the difference between the total cost of labor in the official economy and the after-tax earnings (from work), the greater is the incentive to avoid this difference and to work in the shadow economy. Since this difference depends broadly on the social security burden/payments and the overall tax burden, they are key features of the existence and the increase of the shadow economy.

But even major tax reforms with major tax rate deductions will not lead to a substantial decrease of the shadow economy. ${ }^{9)}$ Such reforms will only be able to stabilize the size of the shadow economy and avoid a further increase. Social networks and personal relationships, the high profit from irregular activities and associated investments in real and human capital are strong ties which prevent people from transferring to the official economy. For Canada, Spiro (1993) found similar reactions of people facing an increase in indirect taxes (VAT, GST). This fact makes it even more difficult for politicians to carry out major reforms because they may not gain a lot from them.

Empirical results of the influence of the tax burden on the shadow economy is provided in the studies of Schneider (1994b, 2000, 2005) and Johnson, Kaufmann and Zoido-Lobatón (1998a, 1998b); they all found statistically significant evidence for the influence of taxation on the shadow economy. This strong influence of indirect and direct taxation on the shadow economy is further demonstrated by discussing empirical results in the case of Austria and the Scandinavian countries. For Austria the driving force for the shadow economy activities is the

\footnotetext{
8) See Thomas (1992); Lippert and Walker (1997); Schneider (1994a,b, 1997, 1998a,b, 2000, 2003b, 2005); Johnson, Kaufmann, and Zoido-Lobatón (1998a,1998b); Tanzi (1999); Giles (1999a); Mummert and Schneider (2001); Giles and Tedds (2002) and Dell'Anno (2003), just to quote a few recent ones.

${ }^{9}$ See Schneider (1994b, 1998b) for a similar result of the effects of a major tax reform in Austria on the shadow economy. Schneider shows that a major reduction in the direct tax burden did not lead to a major reduction in the shadow economy. Because legal tax avoidance was abolished and other factors, like regulations, were not changed; hence for a considerable part of the tax payers the actual tax and regulation burden remained unchanged.
} 
direct tax burden (including social security payments), it has the biggest influence, followed by the intensity of regulation and complexity of the tax system. A similar result has been achieved by Schneider (1986) for the Scandinavian countries (Denmark, Norway and Sweden). In all three countries various tax variables (average direct tax rate, average total tax rate (indirect and direct tax rate)) and marginal tax rates have the expected positive sign (on currency demand) and are highly statistically significant. These findings are supported by studies of Kirchgaessner $(1983,1984)$ for Germany and by Klovland (1984) for Norway and Sweden, too.

In this study an attempt will be made to investigate the influence of the direct and indirect tax burden as well as the social security payments on the shadow economy for developing, transition and highly developed countries. Hence, for the first time this influence is investigated for developing, transition and highly developed countries for the same time period and using the same estimation technique.

\subsubsection{Intensity of Regulations}

The increase of the intensity of regulations (often measured in the numbers of laws and regulations, like licenses requirements) is another important factor, which reduces the freedom (of choice) for individuals engaged in the official economy. ${ }^{10)}$ One can think of labor market regulations, trade barriers, and labor restrictions for foreigners. Johnson, Kaufmann, and Zoido-Lobatón (1998b) find an overall significant empirical evidence of the influence of (labor) regulations on the shadow economy, the impact is clearly described and theoretically derived in other studies, e.g. for Germany (Deregulation Commission 1990/91). Regulations lead to a substantial increase in labor costs in the official economy. But since most of these costs can be shifted on the employees, these costs provide another incentive to work in the shadow economy, where they can be avoided. Empirical evidence supporting the model of Johnson, Kaufmann, and Shleifer (1997), which predicts, inter alia, that countries with more general regulation of their economies tend to have a higher share of the unofficial economy in total GDP, is found in their empirical analysis. A one-point increase of the regulation index (ranging from 1 to 5 , with $5=$ the most regulation in a country), ceteris paribus, is associated with an 8.1 percentage point increase in the share of the shadow economy, when controlled for GDP per capita (Johnson et. al. (1998b), p. 18). They conclude that it is the enforcement

\footnotetext{
${ }^{10)}$ See for a (social) psychological, theoretical foundation of this feature, Brehm $(1966,1972)$, and for a (first)
} 
of regulation, which is the key factor for the burden levied on firms and individuals, and not the overall extent of regulation - mostly not enforced - which drive firms into the shadow economy. Friedman, Johnson, Kaufmann and Zoido-Lobaton (1999) reach a similar result. In their study every available measure of regulation is significantly correlated with the share of the unofficial economy and the sign of the relationship is unambiguous: more regulation is correlated with a larger shadow economy. A one point increase in an index of regulation (ranging from 1-5) is associated with a $10 \%$ increase in the shadow economy for 76 developing, transition and developed countries.

These findings demonstrate that governments should put more emphasis on improving enforcement of laws and regulations, rather than increasing their number. Some governments, however, prefer this policy option (more regulations and laws), when trying to reduce the shadow economy, mostly because it leads to an increase in power of the bureaucrats and to a higher rate of employment in the public sector. In this study the effect of government regulation on the development of the shadow economy will be investigated for developing, transition and highly developed countries.

\subsubsection{Public Sector Services}

An increase of the shadow economy can lead to reduced state revenues which in turn reduce the quality and quantity of publicly provided goods and services. Ultimately, this can lead to an increase in the tax rates for firms and individuals in the official sector, quite often combined with a deterioration in the quality of the public goods (such as the public infrastructure) and of the administration, with the consequence of even stronger incentives to participate in the shadow economy. Johnson, Kaufmann, and Zoido-Lobatón (1998a,b) present a simple model of this relationship. Their findings show that smaller shadow economies appear in countries with higher tax revenues, if achieved by lower tax rates, fewer laws and regulations and less bribery facing enterprises. Countries with a better rule of the law, which is financed by tax revenues, also have smaller shadow economies. Transition countries have higher levels of regulation leading to a significantly higher incidence of bribery, higher effective taxes on official activities and a large discretionary framework of regulations and consequently to a higher shadow economy. Their overall conclusion is that "wealthier countries of the OECD, as well as some in Eastern Europe find themselves in the 'good equilibrium' of relatively low tax and regulatory burden, sizeable revenue mobilization,

application to the shadow economy, Pelzmann (1988). 
good rule of law and corruption control, and [relatively] small unofficial economy. By contrast, a number of countries in Latin American and the Former Soviet Union exhibit characteristics consistent with a 'bad equilibrium': tax and regulatory discretion and burden on the firm is high, the rule of law is weak, and there is a high incidence of bribery and a relatively high share of activities in the unofficial economy." (Johnson, Kaufmann and ZoidoLobatón 1998a p. I). Unfortunately, due to lacking data, for example the effect of corruption on the size of the shadow economy could not be investigated.

\section{The Size of the Shadow Economies all over the World -Findings for 145 Countries}

\subsection{Introductionary Remarks}

In order to calculate the size and development of the shadow economies of 145 countries, the DYMIMIC approach (latent estimation approach - for details see the Appendix) is used. Econometric estimations have been undertaken for the group of African, South and Middle American and Asian developing countries (together with the South Pacific Island countries), for the Transition countries (together with the still Communist countries) and for the highly developed OECD countries. One disadvantage of the DYMIMIC approach is, that one gets only relative estimated sizes of the shadow economy and one has to use another approach (in our case, the currency demand approach) to get absolute figures. In order to calculate absolute figures of the size of the shadow economies from these DYMIMIC estimation results the author used the already available estimations from the currency demand approach in combination with the DYMIMIC approach for Australia, Austria, Germany, Hungary, Italy, India, Peru, Russia and the United States (from studies of Chatterjee, Chaudhury and Schneider (2003), Del'Anno and Schneider (2004), Bajada and Schneider (2003), Alexeev and Pyle (2003), Schneider and Enste (2002) and Lacko (2000)). With the help of the absolute values of the shadow economy (in \% of GDP) for these countries the absolute values of the shadow economy for all other countries could be calculated. The results are shown in the next section.

3.2 The Size of the Shadow Economies for 145 Countries for 1999/2000, 


\section{1/2002 and 2002/2003}

When showing the size of the shadow economies over the three periods of time $(1999 / 2000$, 2001/2002 and 2002/2003) for the 145 countries which are quite different in location and developing stage, one should be aware that such country comparison give only a rough picture of the ranking of the size of the shadow economy over the countries and over time, because the DYMIMIC and the currency demand methods have short comings which are discussed in appendix (chapter 5) see also Thomas (1992, 1999), Tanzi (1999), Pedersen (2003) and Ahumada, Alveredo, Cavanese A and P. Cavanese (2004), and Schneider (2005)). Due to these shortcomings a detailed discussion of the (relative) ranking of the size of the shadow economies is not done.

\subsubsection{Developing Countries ${ }^{11}$}

The results of the shadow economies for the developing countries are grouped for Africa, Asia and Central and South America, ${ }^{12)}$ and are shown in tables 3.1.-3.3 and figures 3.1.13.3.3. The results for 37 African countries are shown in table 3.1. If I first consider the development of the shadow economy of these 37 African countries over the three periods of time, I realize that shadow economy in these African nations has increased. On average, the size of these 37 African shadow economies was 41.3\% of official GDP in 1999/2000 and increased to $43.2 \%$ in $2002 / 2003$. This is an increase of 0.9 percentage points over four years (on average). If I now turn to the latest results for 2002/2003 Zimbabwe, Tanzania and Nigeria (with 63.2, 60.2 and 59.4\% respectively) have by far the largest shadow economies; the median country is Mozambique with $42.4 \%$ and the lowest shadow economy has South Africa with $29.5 \%$, followed by Lesotho with $33.3 \%$ and Namibia with $33.4 \%$.

\footnotetext{
${ }^{11}$ For an extensive and excellent literature survey of the research about the shadow economy in developing countries see Gerxhani (2003), who stresses thorough out her paper that the destination between developed and developing countries with respect to the shadow economy is of great importance. Due to space reasons this point is not further elaborated here also the former results and literature are not discussed here.

12) The disadvantage of these grouping is that in Asia we have also highly developed countries like Singapore. and also in Africa the state of South-Africa.
} 
Table 3.1: The Size of the Shadow Economy in 37 African Countries

\begin{tabular}{|c|c|c|c|c|}
\hline \multirow[b]{2}{*}{ No. } & \multirow[b]{2}{*}{ Country } & \multicolumn{3}{|c|}{$\begin{array}{l}\text { Shadow Economy (in \% of off. GDP) using } \\
\text { the DYMIMIC and Currency Demand Method }\end{array}$} \\
\hline & & $1999 / 00$ & $2001 / 02$ & $2002 / 03$ \\
\hline 1 & Algeria & 34,1 & 35,0 & 35,6 \\
\hline 2 & Angola & 43,2 & 44,1 & 45,2 \\
\hline 3 & Benin & 47,3 & 48,2 & 49,1 \\
\hline 4 & Botswana & 33,4 & 33,9 & 34,6 \\
\hline 5 & Burkina Faso & 41,4 & 42,6 & 43,3 \\
\hline 6 & Burundi & 36,9 & 37,6 & 38,7 \\
\hline 7 & Cameroon & 32,8 & 33,7 & 34,9 \\
\hline 8 & Central African Republic & 44,3 & 45,4 & 46,1 \\
\hline 9 & Chad & 46,2 & 47,1 & 48,0 \\
\hline 10 & Congo, Dem. Rep. & 48,0 & 48,8 & 49,7 \\
\hline 11 & Congo, Rep. & 48,2 & 49,1 & 50,1 \\
\hline 12 & Cote d'Ivoire & 43,2 & 44,3 & 45,2 \\
\hline 13 & Egypt, Arab Rep. & 35,1 & 36,0 & 36,9 \\
\hline 14 & Ethiopia & 40,3 & 41,4 & 42,1 \\
\hline 15 & Ghana & 41,9 & 42,7 & 43,6 \\
\hline 16 & Guinea & 39,6 & 40,8 & 41,3 \\
\hline 17 & Kenya & 34,3 & 35,1 & 36,0 \\
\hline 18 & Lesotho & 31,3 & 32,4 & 33,3 \\
\hline 19 & Madagascar & 39,6 & 40,4 & 41,6 \\
\hline 20 & Malawi & 40,3 & 41,2 & 42,1 \\
\hline 21 & Mali & 42,3 & 43,9 & 44,7 \\
\hline 22 & Mauritania & 36,1 & 37,2 & 38,0 \\
\hline 23 & Morocco & 36,4 & 37,1 & 37,9 \\
\hline 24 & Mozambique & 40,3 & 41,3 & 42,4 \\
\hline 25 & Namibia & 31,4 & 32,6 & 33,4 \\
\hline 26 & Niger & 41,9 & 42,6 & 43,8 \\
\hline 27 & Nigeria & 57,9 & 58,6 & 59,4 \\
\hline 28 & Rwanda & 40,3 & 41,4 & 42,2 \\
\hline 29 & Senegal & 45,1 & 46,8 & 47,5 \\
\hline 30 & Sierra Leone & 41,7 & 42,8 & 43,9 \\
\hline 31 & South Africa & 28,4 & 29,1 & 29,5 \\
\hline 32 & Tanzania & 58,3 & 59,4 & 60,2 \\
\hline 33 & Togo & 35,1 & 39,2 & 40,4 \\
\hline 34 & Tunisia & 38,4 & 39,1 & 39,9 \\
\hline 35 & Uganda & 43,1 & 44,6 & 45,4 \\
\hline 36 & Zambia & 48,9 & 49,7 & 50,8 \\
\hline 37 & Zimbabwe & 59,4 & 61,0 & 63,2 \\
\hline \multicolumn{2}{|c|}{ Unweighted Average } & 41,3 & 42,3 & 43,2 \\
\hline
\end{tabular}




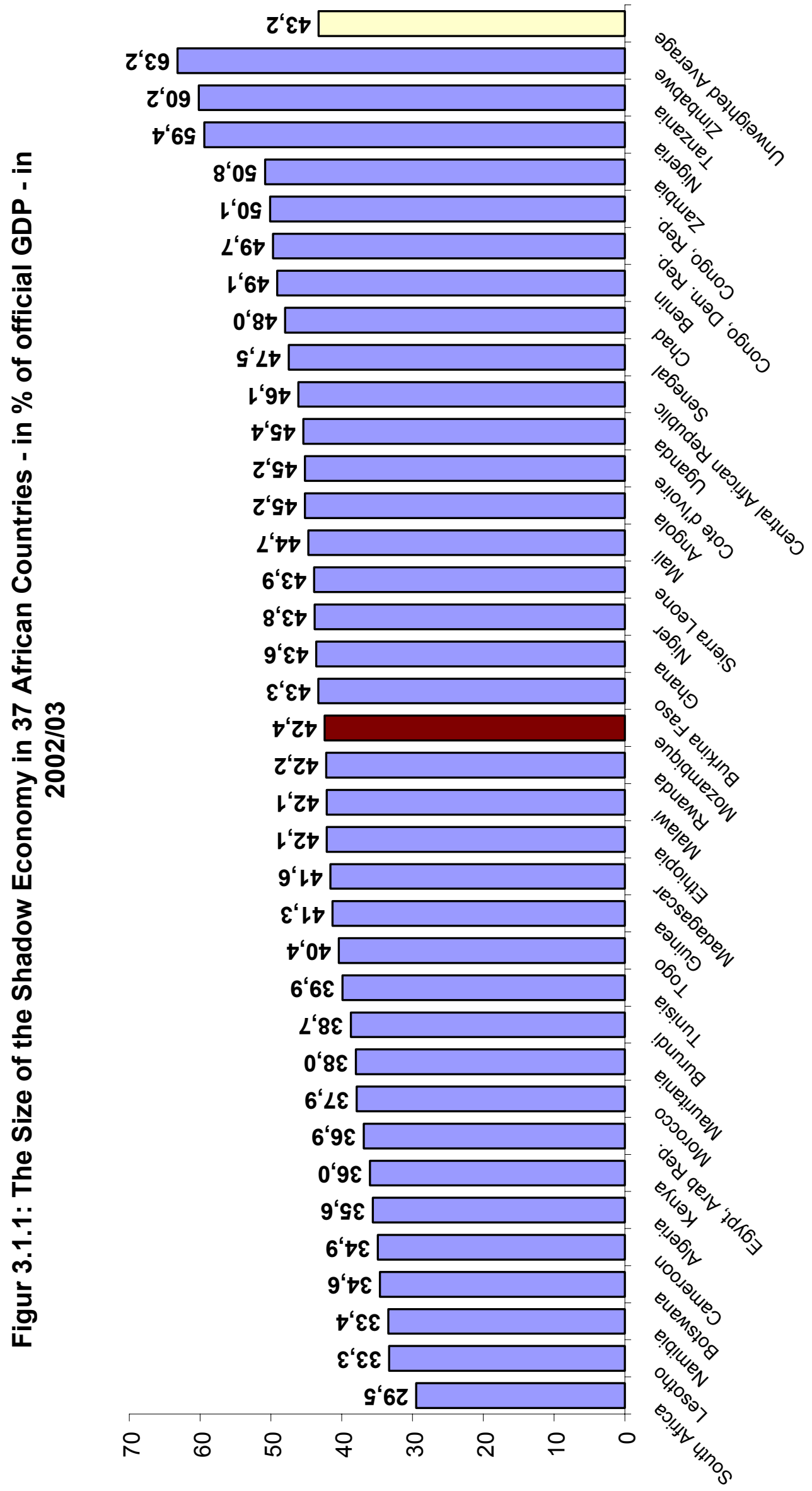



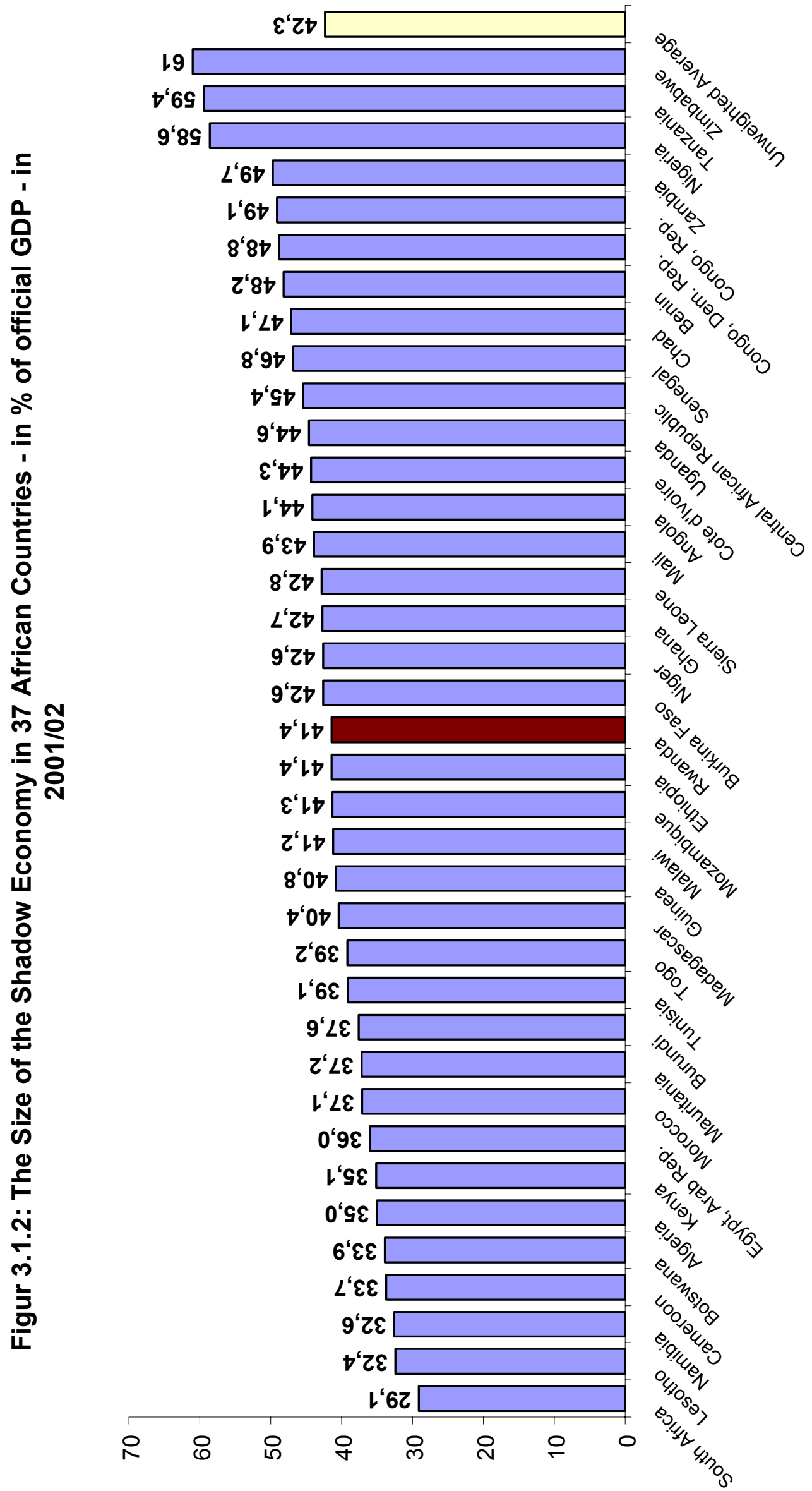

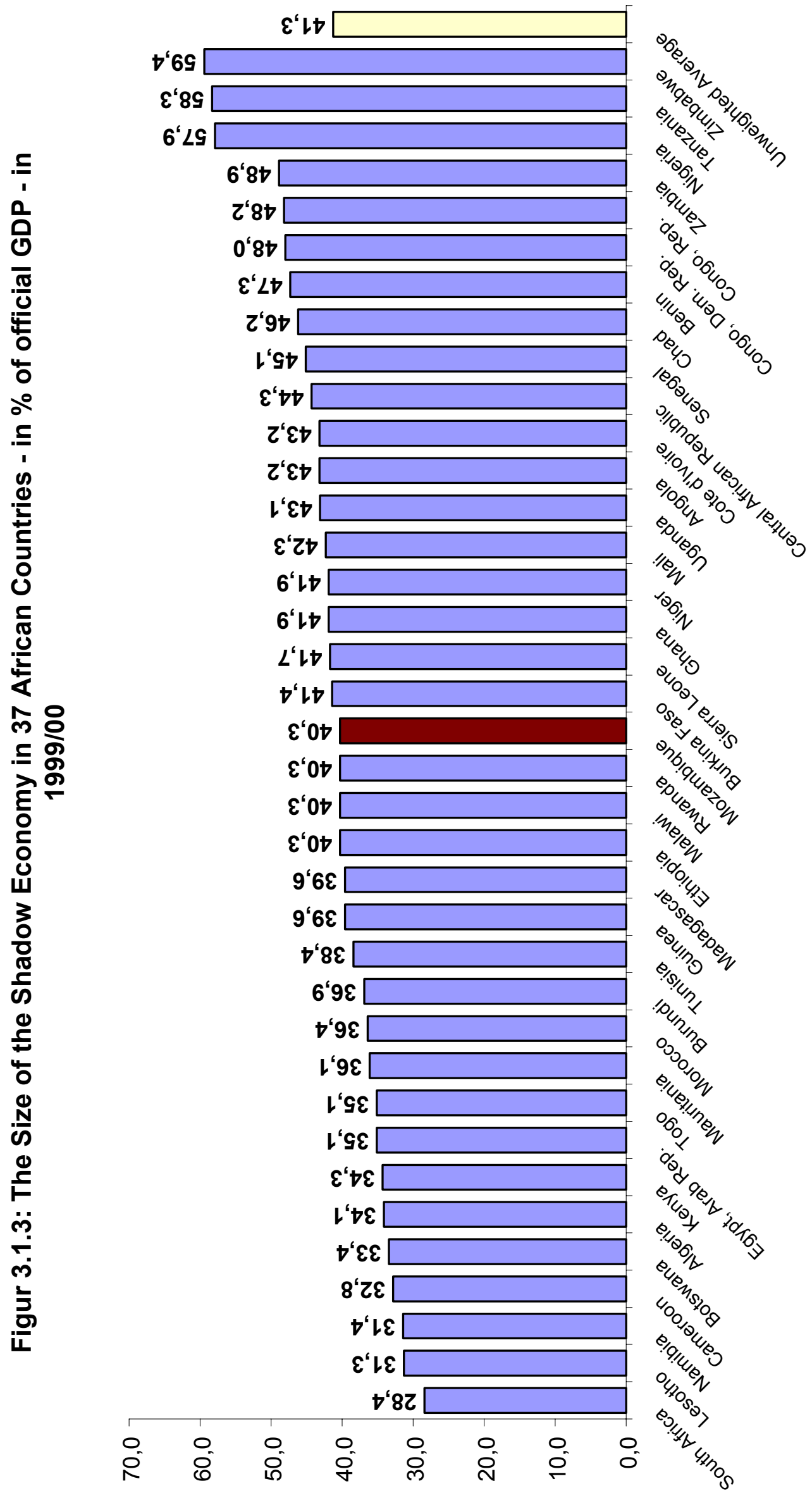
In table 3.2 and figures 3.2.1-3.2.3 the results for 27 Asian countries are shown, recognizing that it is somewhat difficult to treat all Asian countries equally because Israel, Singapore and Hongkong are highly developed countries and others (like Thailand, Nepal) are more or less developing countries. If I again discuss first the development of the shadow economy over the period 1999/2000 and 2002/2003 the average shadow economy of these 27 Asian countries increased from $28.9 \%$ in $1999 / 2000$ to $30.8 \%$ of official GDP in $2002 / 2003$, which is an increase of 1.9 percentage points for these four years.

Table 3.2: The Size of the Shadow Economy in 27 Asian Countries

\begin{tabular}{|c|c|c|c|c|}
\hline \multirow[b]{2}{*}{ No. } & \multirow[b]{2}{*}{ Country } & \multicolumn{3}{|c|}{$\begin{array}{l}\text { Shadow Economy (in \% of off. GDP) using the } \\
\text { DYMIMIC and Currency Demand Method }\end{array}$} \\
\hline & & $1999 / 00$ & $2001 / 02$ & $2002 / 03$ \\
\hline 1 & Bangladesh & 35,6 & 36,5 & 37,7 \\
\hline 2 & Bhutan & 29,4 & 30,5 & 31,7 \\
\hline 3 & Cambodia & 50,1 & 51,3 & 52,4 \\
\hline 4 & Hong Kong, China & 16,6 & 17,1 & 17,2 \\
\hline 5 & India & 23,1 & 24,2 & 25,6 \\
\hline 6 & Indonesia & 19,4 & 21,8 & 22,9 \\
\hline 7 & Iran, Islamic Rep. & 18,9 & 19,4 & 19,9 \\
\hline 8 & Israel & 21,9 & 22,8 & 23,9 \\
\hline 9 & Jordan & 19,4 & 20,5 & 21,6 \\
\hline 10 & Korea, Rep. & 27,5 & 28,1 & 28,8 \\
\hline 11 & Kuwait & 20,1 & 20,7 & 21,6 \\
\hline 12 & Lebanon & 34,1 & 35,6 & 36,2 \\
\hline 13 & Malaysia & 31,1 & 31,6 & 32,2 \\
\hline 14 & Nepal & 38,4 & 39,7 & 40,8 \\
\hline 15 & Oman & 18,9 & 19,4 & 19,8 \\
\hline 16 & Pakistan & 36,8 & 37,9 & 38,7 \\
\hline 17 & Papua New Guinea & 36,1 & 37,3 & 38,6 \\
\hline 18 & Philippines & 43,4 & 44,5 & 45,6 \\
\hline 19 & Saudi Arabia & 18,4 & 19,1 & 19,7 \\
\hline 20 & Singapore & 13,1 & 13,4 & 13,7 \\
\hline 21 & Sri Lanka & 44,6 & 45,9 & 47,2 \\
\hline 22 & Syrian Arab Republic & 19,3 & 20,4 & 21,6 \\
\hline 23 & Taiwan, China & 25,4 & 26,6 & 27,7 \\
\hline 24 & Thailand & 52,6 & 53,4 & 54,1 \\
\hline 25 & Turkey & 32,1 & 33,2 & 34,3 \\
\hline 26 & United Arab Emirates & 26,4 & 27,1 & 27,8 \\
\hline 27 & Yemen, Rep. & 27,4 & 28,4 & 29,1 \\
\hline \multicolumn{2}{|c|}{ Unweighted Average } & 28,9 & 29,9 & 30,8 \\
\hline
\end{tabular}

If I now consider the results of the single the shadow economies of these 27 Asian countries ${ }^{13)}$ for the latest period, $2002 / 2003$, Thailand has with $54.1 \%$ by far the largest shadow economy, followed by Cambodia with $52.4 \%$ and Sri Lanka with $47.2 \%$ of official GDP. The median country is the Korean Republic with $28.2 \%$ of official GDP, surrounded by Yemen with $29.1 \%$ and United Arab Emirates with 27.8\%. Singapore, Hongkong and Saudi Arabia have the lowest shadow economies with 13.7\%, $17.2 \%$ and $19.7 \%$ of official GDP, respectively.

\footnotetext{
${ }^{13)}$ The case of India has been extensively investigated by Chatterjee, Chaudhury and Schneider (2003).
} 


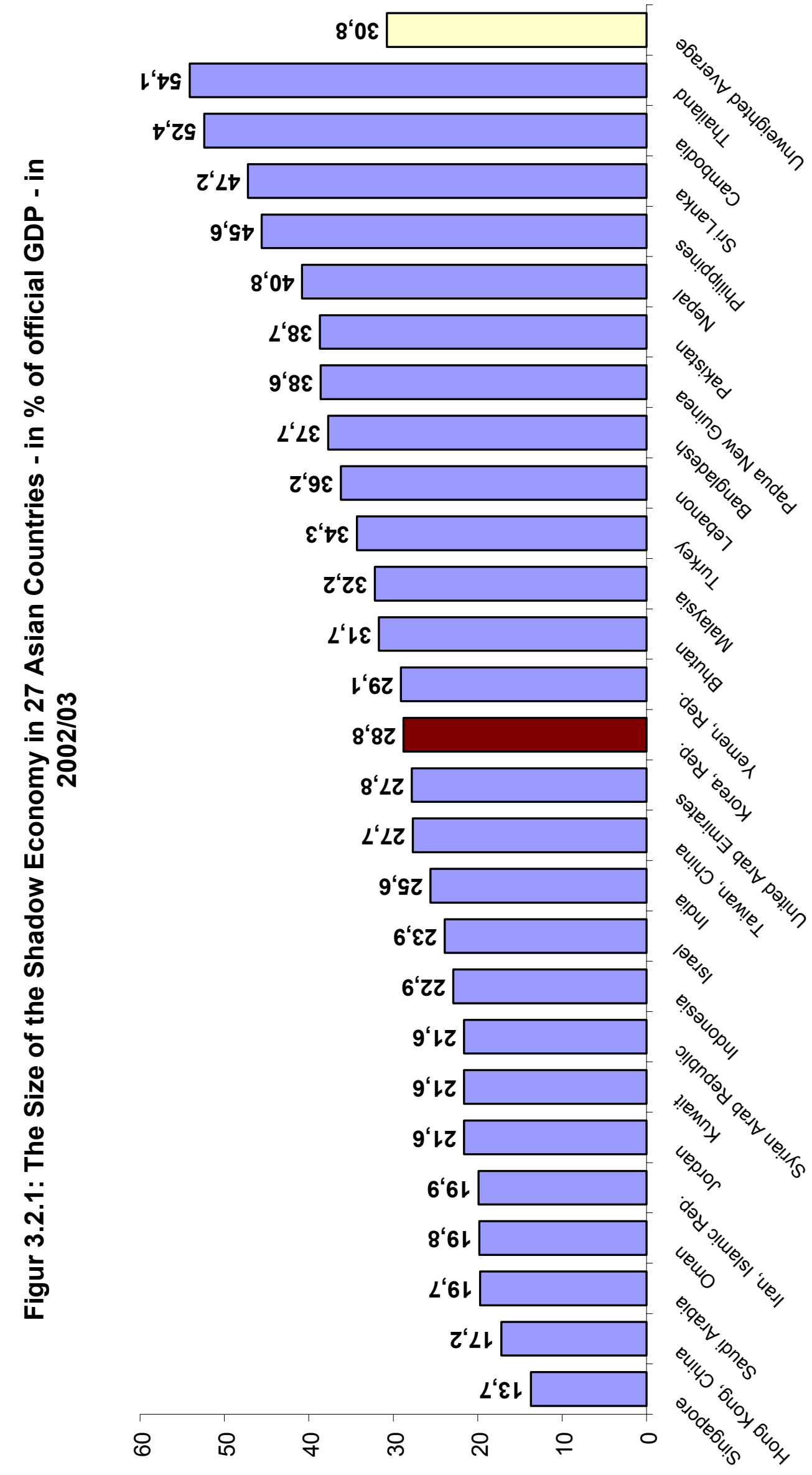



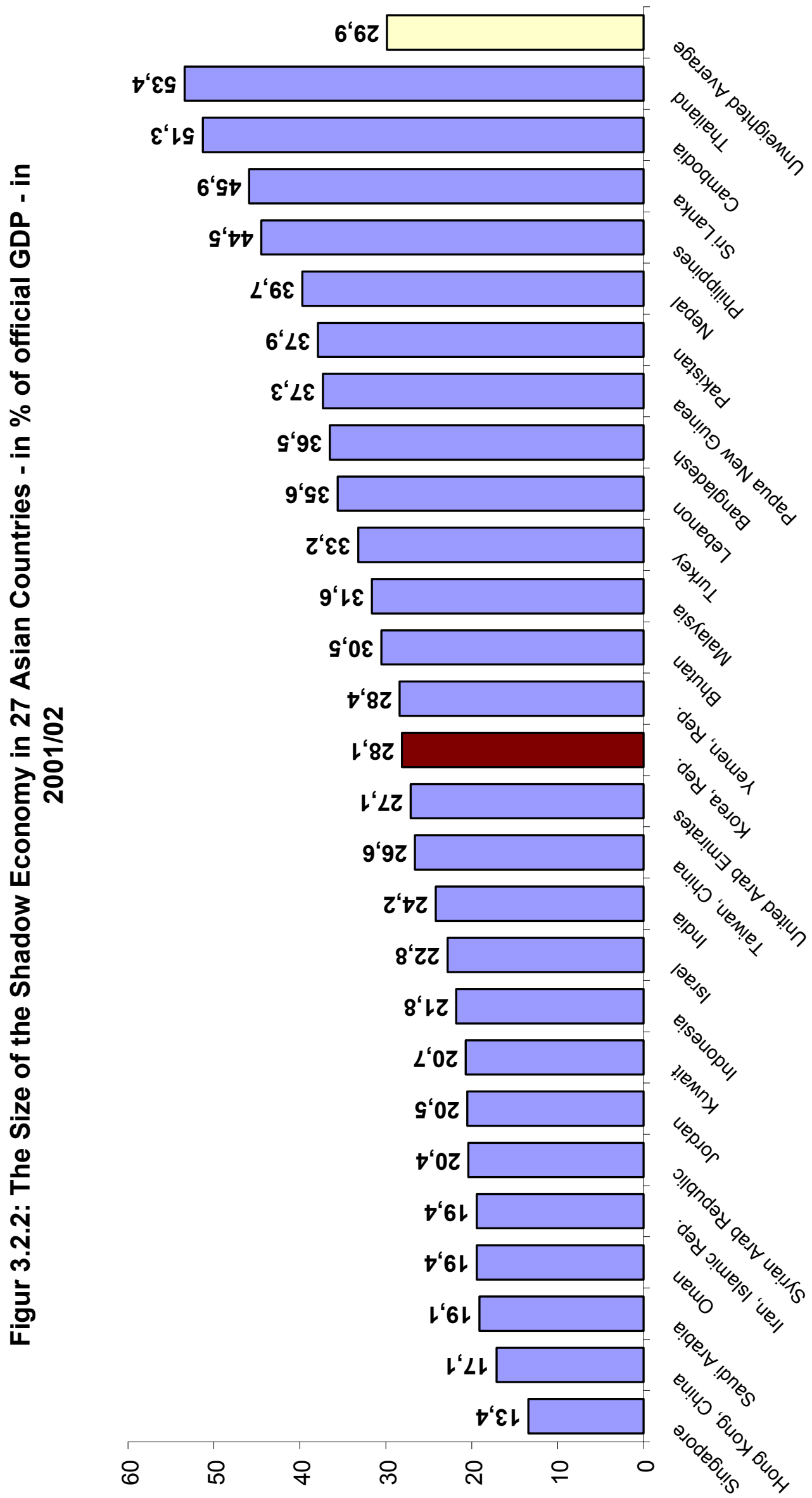

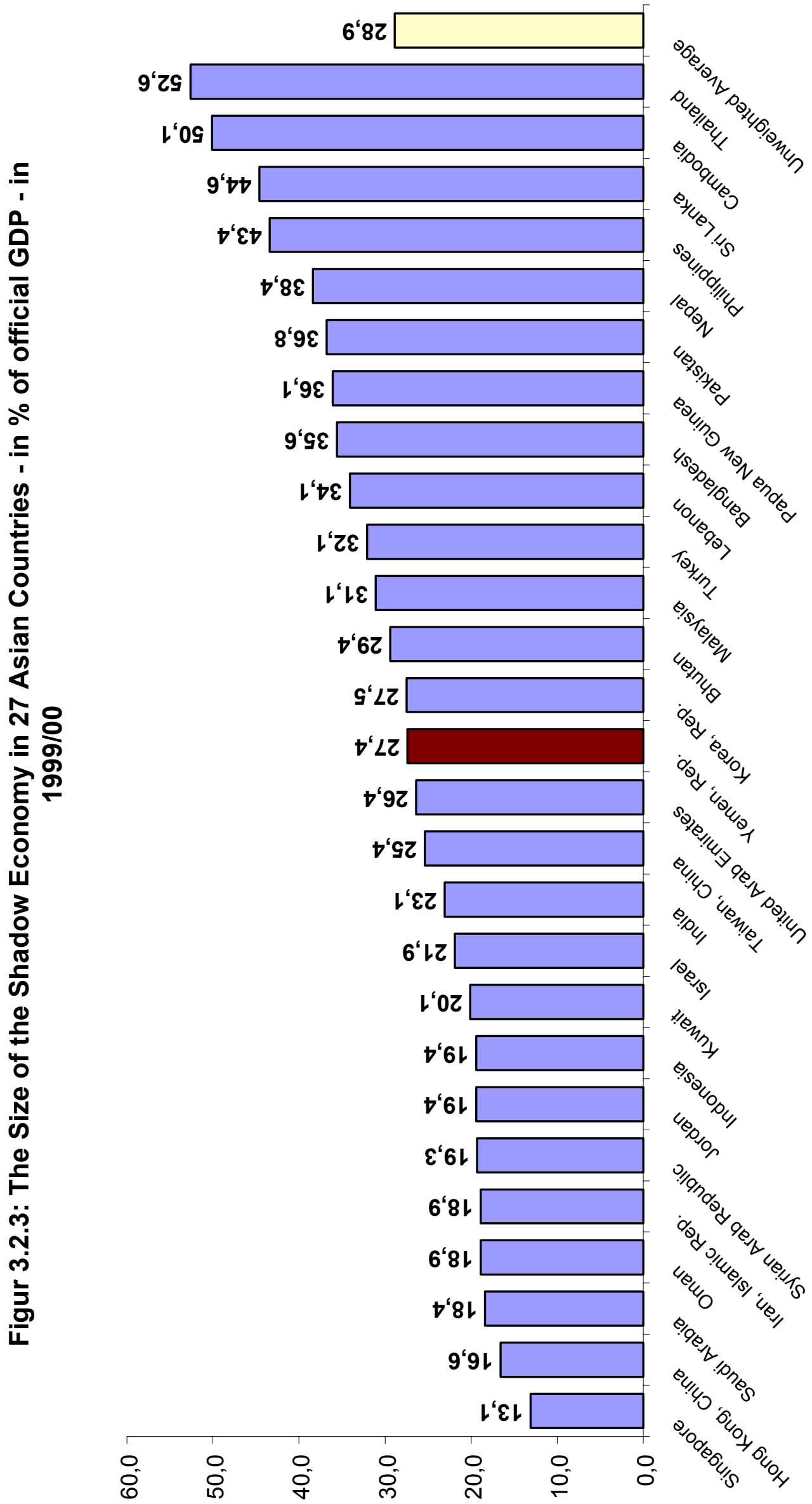
One realizes, that the average size of the Asian shadow economies is considerably lower compared with the ones of African and South and Latin American states - partly due to the fact that in Asia there is a greater number of developed (already) industrialized countries with lower shadow economies.

In table 3.3 the results of the sizes of the shadow economies for the three periods of time (1999/2000, 2001/2002, 2002/2003) for 21 Central and South American countries are shown. Discussing again first the development of the shadow economy over time in all 21 Central and South American countries it has increased from $41.1 \%$ in the year $1999 / 2000$ to $43.4 \%$ of official GDP in the year $2002 / 2003$, which is an increase of 2.3 percentage points over these four years. If I now turn to the size of the shadow economy for single, Central and Latin American countries for the latest period 2002/2003 the largest shadow economy has Bolivia with $68.3 \%$, followed by Panama with $65.3 \%$ and Peru with $60.9 \%$ of official GDP. The median country is Brazil with $42.3 \%$ and at the lower end are Chile with $20.9 \%$, Costa Rica with $27.8 \%$ and Argentina with $28.9 \%$ of official GDP. In general the average sizes of the shadow economies of South and Latin American countries and the ones of Africa are quite similar.

Table 3.3: The Size of the Shadow Economy in 21 Central and South American Countries

\begin{tabular}{|r|l|r|r|r|}
\hline \multirow{2}{*}{} & \multirow{2}{*}{ No. } & \multicolumn{3}{|c|}{$\begin{array}{c}\text { Shadow Economy (in \% of off. GDP) using the } \\
\text { DYMIMIC and Currency Demand Method }\end{array}$} \\
\cline { 2 - 5 } & Country & Argentina & $\mathbf{1 9 9 9 / 0 0}$ & \multicolumn{2}{|c|}{$\mathbf{2 0 0 1 / 0 2}$} & $\mathbf{2 0 0 2 / 0 3}$ \\
2 & Bolivia & 25,4 & 27,1 & 28,9 \\
3 & Brazil & 67,1 & 68,1 & 68,3 \\
4 & Chile & 39,8 & 40,9 & 42,3 \\
5 & Colombia & 19,8 & 20,3 & 20,9 \\
6 & Costa Rica & 39,1 & 41,3 & 43,4 \\
7 & Dominican Republic & 26,2 & 27,0 & 27,8 \\
8 & Ecuador & 32,1 & 33,4 & 34,1 \\
9 & El Salvador & 34,4 & 35,1 & 36,7 \\
10 & Guatemala & 46,3 & 47,1 & 48,3 \\
11 & Haiti & 51,5 & 51,9 & 52,4 \\
12 & Honduras & 55,4 & 57,1 & 58,6 \\
13 & Jamaica & 49,6 & 50,8 & 51,6 \\
14 & Mexico & 36,4 & 37,8 & 38,9 \\
15 & Nicaragua & 30,1 & 31,8 & 33,2 \\
16 & Panama & 45,2 & 46,9 & 48,2 \\
17 & Paraguay & 64,1 & 65,1 & 65,3 \\
18 & Peru & 27,4 & 29,2 & 31,4 \\
19 & Puerto Rico & 59,9 & 60,3 & 60,9 \\
20 & Uruguay & 28,4 & 29,4 & 30,7 \\
21 & Venezuela, RB & 51,1 & 51,4 & 51,9 \\
\hline Unweighted Average & 33,6 & $\mathbf{4 1 , 1}$ & & 36,7 \\
\hline
\end{tabular}




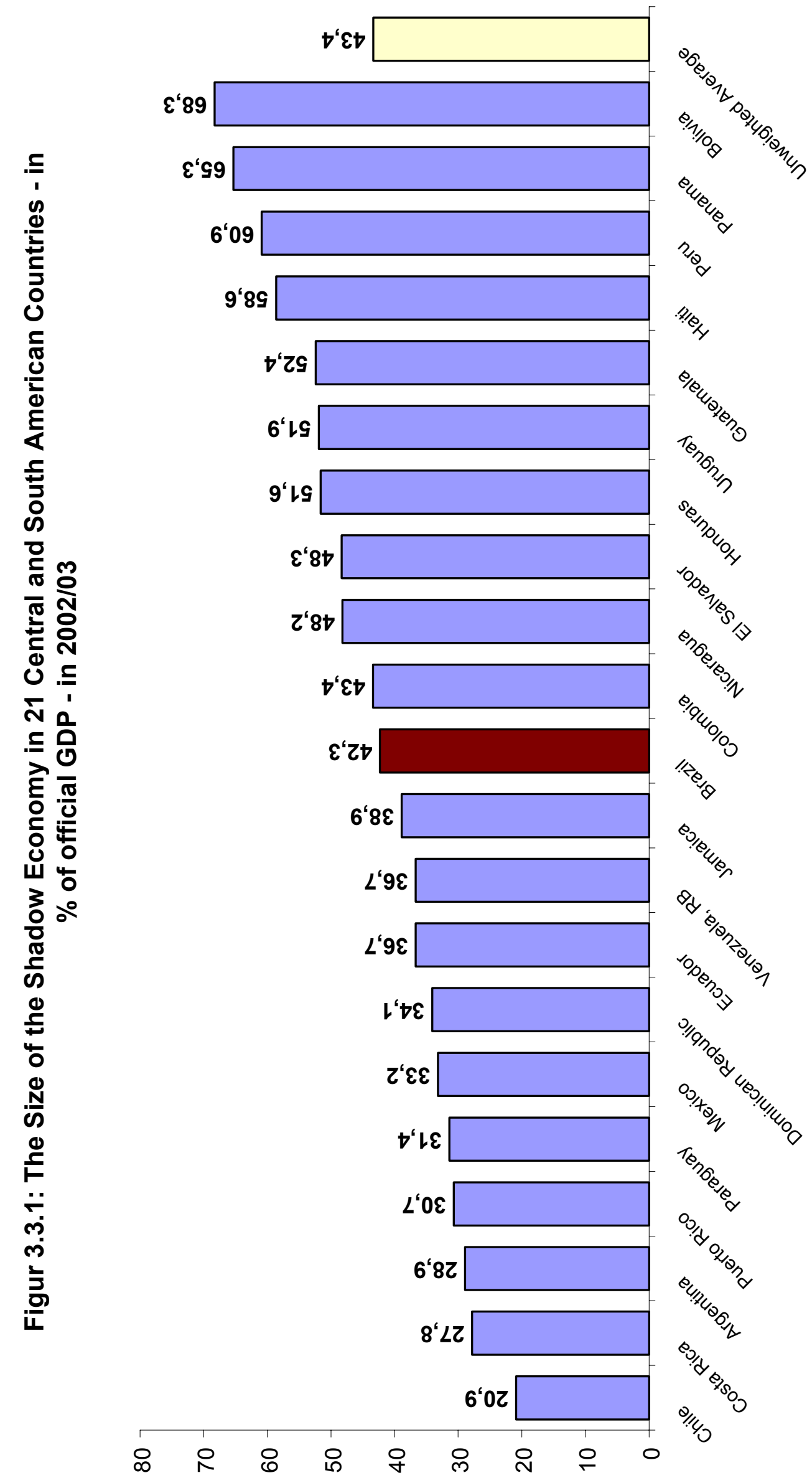




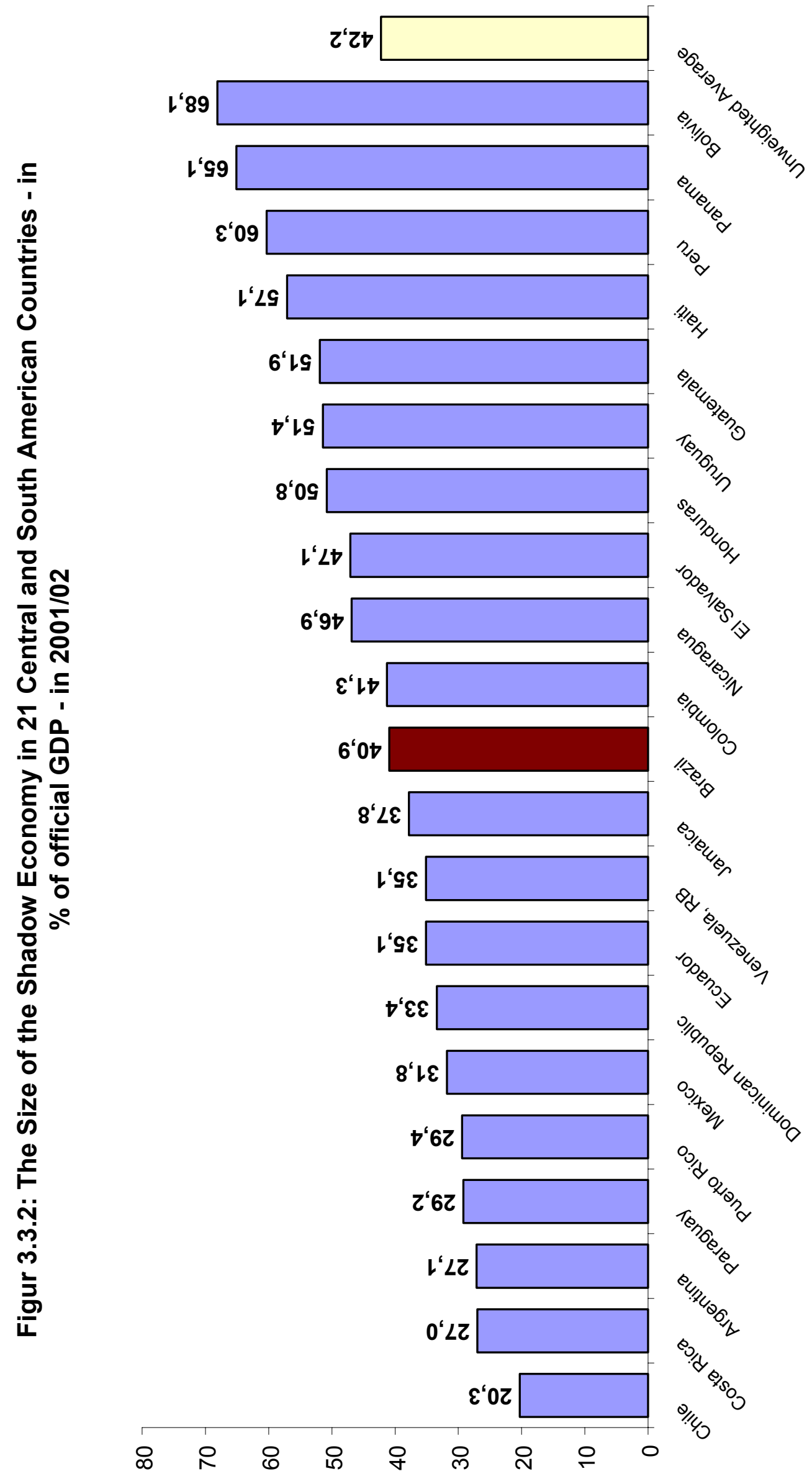



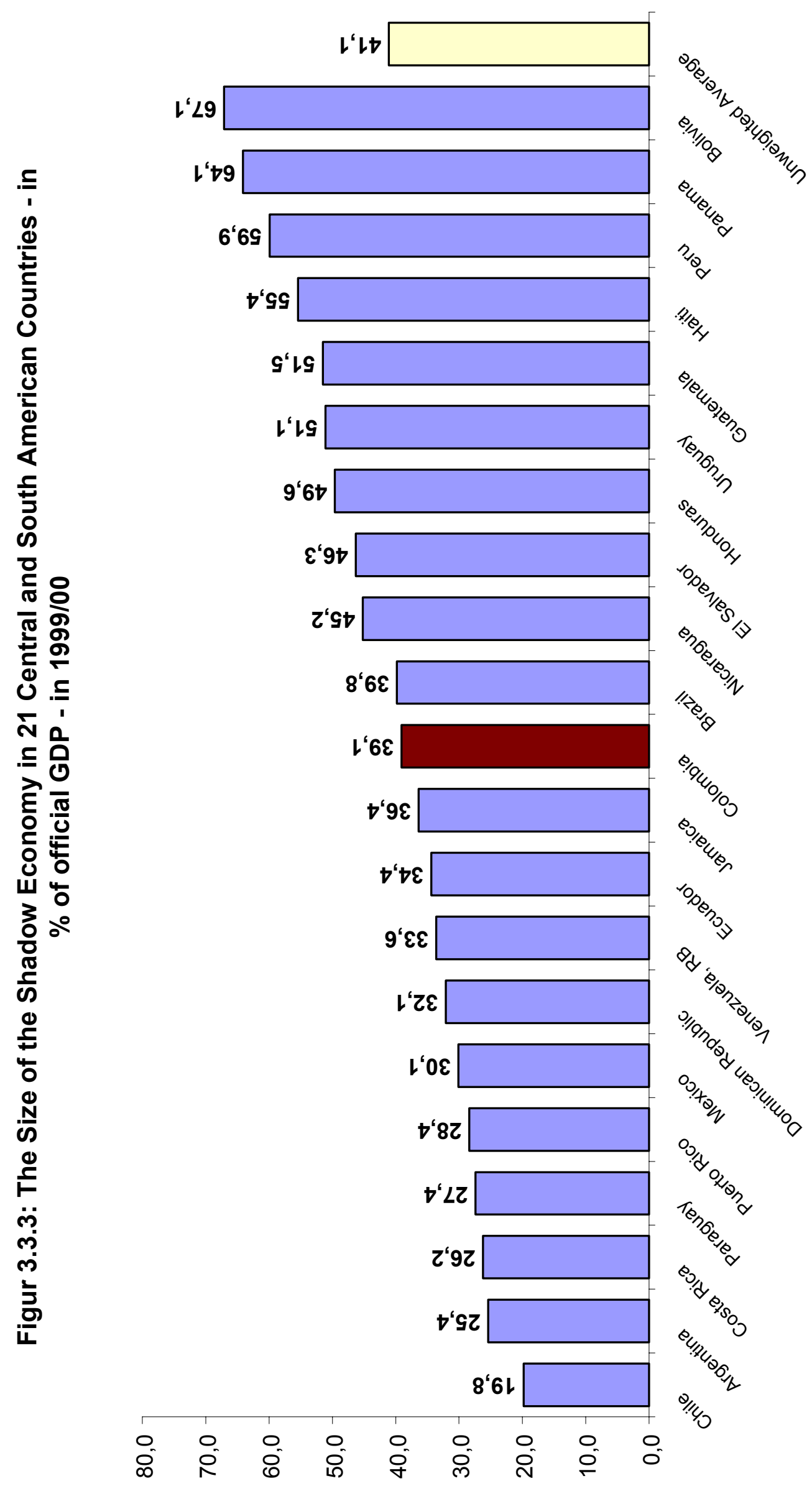


\subsubsection{Transition Countries}

The measurement of the size and development of the shadow economy in the transition countries has been undertaken since the late 80s starting with the work of Kaufmann and Kaliberda (1996), Johnson et.al. (1997) and Lacko (2000). They all are using the physical input (electricity) method (see Appendix 7.1.2.5) and come up with quite large figures. In the work of Alexeev and Pyle (2003) and Belev (2003) the above mentioned studies are critically evaluated arguing that the estimated sizes of the unofficial economies are to a large content a historical phenomenon and partly determined by institutional factors.

In table 3.4 and figures 3.4.1-3.4.3 the size and development of the shadow economy of 25 East and Central European and Former Soviet Union countries are presented. Turning again first to the development of the size of the shadow economy over time, the average size of the shadow economy of these 25 East and Central European countries was 38.1\% of official GDP in $1999 / 2000$ and increased to $40.1 \%$ in $2002 / 2003$ which is an increase of 2 percentage points over these four years. The highest shadow economies have Georgia, Azerbaijan and the Ukraine with $68.0 \%, 61.3 \%$ and $54.7 \%$. The median country is Bulgaria, surrounded by Serbia and Montenegro of $39.1 \%$ and Romania of $37.4 \%$. At the lower end are the Czech Republic with $20.1 \%$, the Slovak Republic with $20.2 \%$ and Hungary with $26.2 \%$ of official GDP. 
Table 3.4: The Size of the Shadow Economy in 25 East and Central European and Former Soviet Union Countries

\begin{tabular}{|c|c|c|c|c|}
\hline \multirow[b]{2}{*}{ No. } & \multirow[b]{2}{*}{ Country } & \multicolumn{3}{|c|}{$\begin{array}{l}\text { Shadow Economy (in \% of off. GDP) using the } \\
\text { DYMIMIC and Currency Demand Method }\end{array}$} \\
\hline & & $1999 / 00$ & $2001 / 02$ & $2002 / 03$ \\
\hline 1 & Albania & 33,4 & 34,6 & 35,3 \\
\hline 2 & Armenia & 46,3 & 47,8 & 49,1 \\
\hline 3 & Azerbaijan & 60,6 & 61,1 & 61,3 \\
\hline 4 & Belarus & 48,1 & 49,3 & 50,4 \\
\hline 5 & Bosnia and Herzegovina & 34,1 & 35,4 & 36,7 \\
\hline 6 & Bulgaria & 36,9 & 37,1 & 38,3 \\
\hline 7 & Croatia & 33,4 & 34,2 & 35,4 \\
\hline 8 & Czech Republic & 19,1 & 19,6 & 20,1 \\
\hline 9 & Estonia & 38,4 & 39,2 & 40,1 \\
\hline 10 & Georgia & 67,3 & 67,6 & 68,0 \\
\hline 11 & Hungary & 25,1 & 25,7 & 26,2 \\
\hline 12 & Kazakhstan & 43,2 & 44,1 & 45,2 \\
\hline 13 & Kyrgyz Republic & 39,8 & 40,3 & 41,2 \\
\hline 14 & Latvia & 39,9 & 40,7 & 41,3 \\
\hline 15 & Lithuania & 30,3 & 31,4 & 32,6 \\
\hline 16 & Macedonia, FYR & 34,1 & 35,1 & 36,3 \\
\hline 17 & Moldova & 45,1 & 47,3 & 49,4 \\
\hline 18 & Poland & 27,6 & 28,2 & 28,9 \\
\hline 19 & Romania & 34,4 & 36,1 & 37,4 \\
\hline 20 & Russian Federation & 46,1 & 47,5 & 48,7 \\
\hline 21 & Serbia and Montenegro & 36,4 & 37,3 & 39,1 \\
\hline 22 & Slovak Republic & 18,9 & 19,3 & 20,2 \\
\hline 23 & Slovenia & 27,1 & 28,3 & 29,4 \\
\hline 24 & Ukraine & 52,2 & 53,6 & 54,7 \\
\hline 25 & Uzbekistan & 34,1 & 35,7 & 37,2 \\
\hline \multicolumn{2}{|c|}{ Unweighted Average } & 38,1 & 39,1 & 40,1 \\
\hline
\end{tabular}



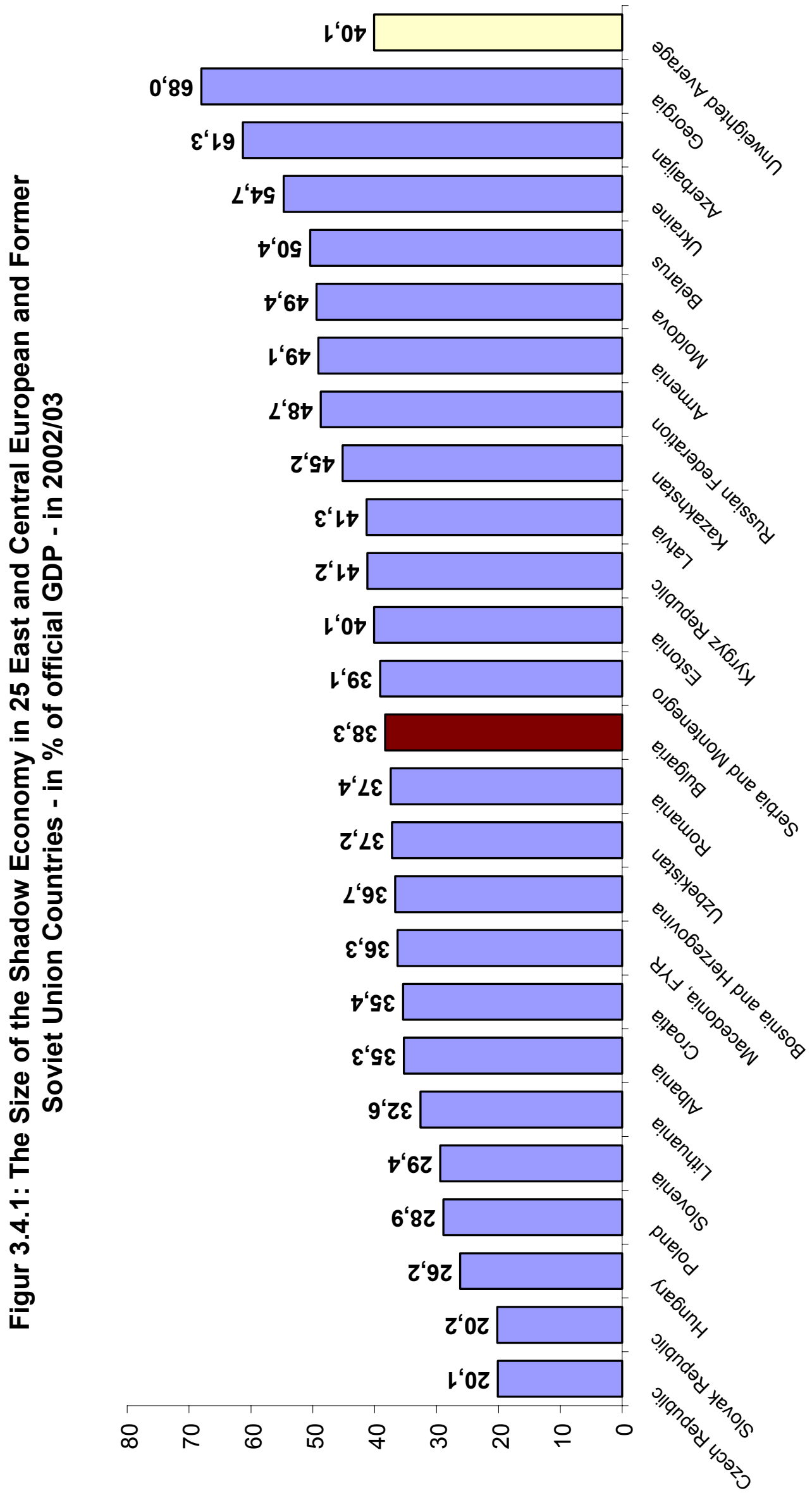

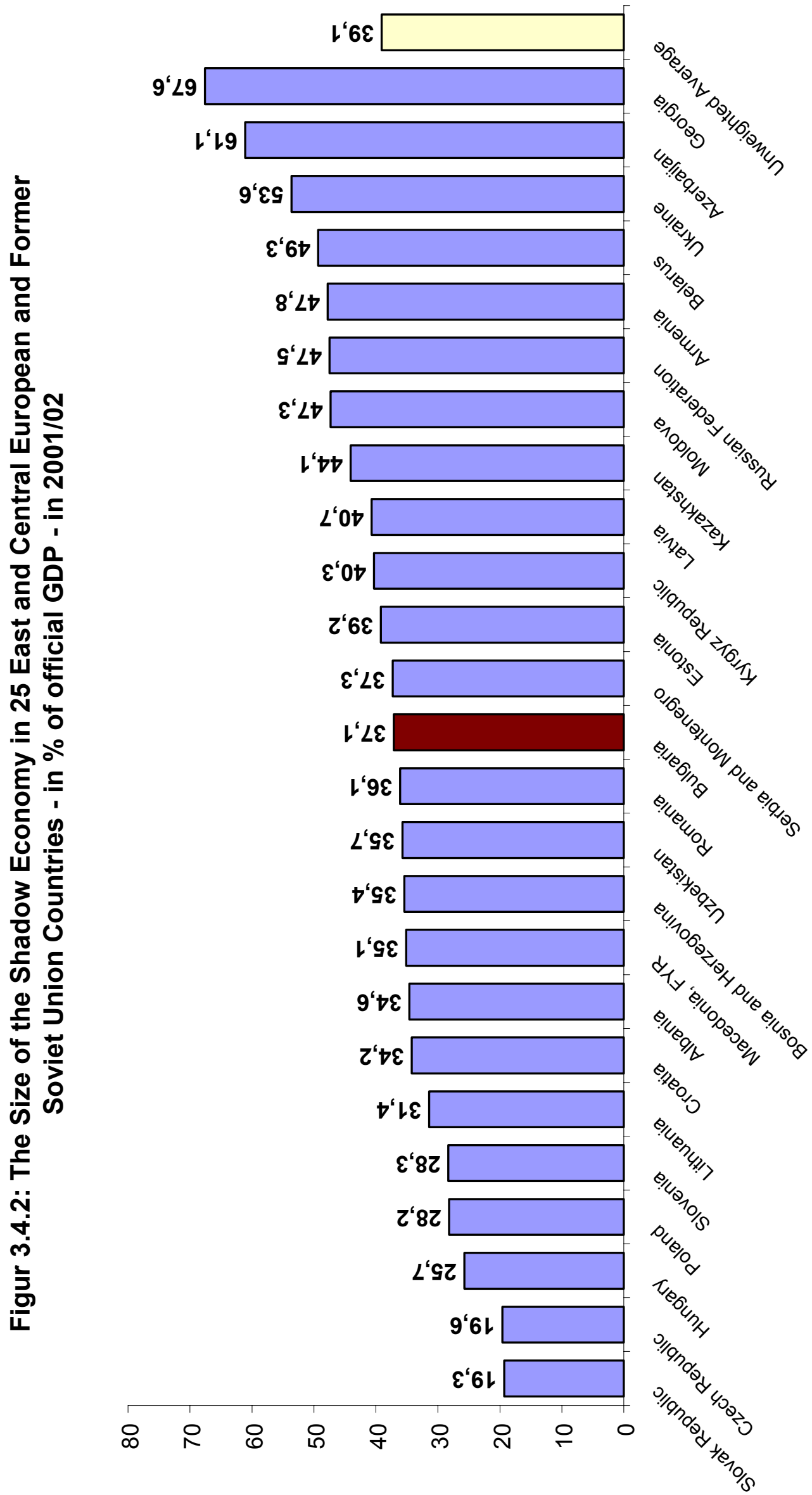

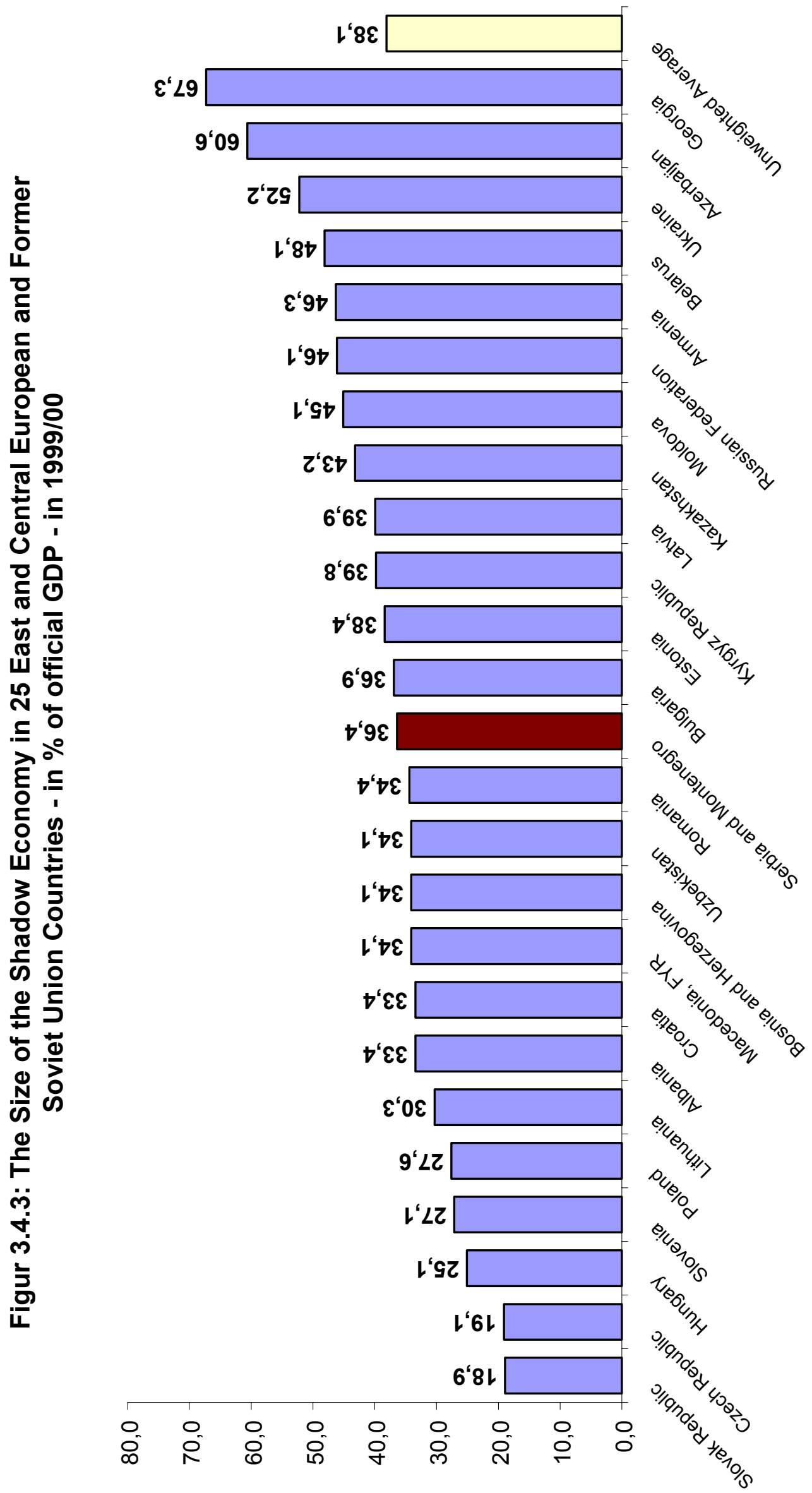


\subsubsection{Highly developed OECD-Countries}

The size and development of 21 highly developed OECD countries is shown in table 3.5 and figures 3.5.1-3.5.3.

Table 3.5: The Size of the Shadow Economy in 21 OECD Countries

\begin{tabular}{|c|c|c|c|c|}
\hline & \multirow[b]{2}{*}{ Country } & \multicolumn{3}{|c|}{$\begin{array}{l}\text { Shadow Economy (in \% of off. GDP) using the DYMIMIC } \\
\text { and Currency Demand Method }\end{array}$} \\
\hline & & $1999 / 00$ & $2001 / 02$ & $2002 / 03$ \\
\hline 1 & Australia & 14,3 & 14,1 & 13,5 \\
\hline 2 & Austria & 9,8 & 10,6 & 10,9 \\
\hline 3 & Belgium & 22,2 & 22,0 & 21,0 \\
\hline 4 & Canada & 16,0 & 15,8 & 15,2 \\
\hline 5 & Denmark & 18,0 & 17,9 & 17,3 \\
\hline 6 & Finland & 18,1 & 18,0 & 17,4 \\
\hline 7 & France & 15,2 & 15,0 & 14,5 \\
\hline 8 & Germany & 16,0 & 16,3 & 16,8 \\
\hline 9 & Greece & 28,7 & 28,5 & 28,2 \\
\hline 10 & Ireland & 15,9 & 15,7 & 15,3 \\
\hline 11 & Italy & 27,1 & 27,0 & 25,7 \\
\hline 12 & Japan & 11,2 & 11,1 & 10,8 \\
\hline 13 & Netherlands & 13,1 & 13,0 & 12,6 \\
\hline 14 & New Zealand & 12,8 & 12,6 & 12,3 \\
\hline 15 & Norway & 19,1 & 19,0 & 18,4 \\
\hline 16 & Portugal & 22,7 & 22,5 & 21,9 \\
\hline 17 & Spain & 22,7 & 22,5 & 22,0 \\
\hline 18 & Sweden & 19,2 & 19,1 & 18,3 \\
\hline 19 & Switzerland & 8,6 & 9,4 & 9,4 \\
\hline 20 & United Kingdom & 12,7 & 12,5 & 12,2 \\
\hline 21 & United States & 8,7 & 8,7 & 8,4 \\
\hline \multicolumn{2}{|c|}{ Unweighted Average } & 16,8 & 16,7 & 16,3 \\
\hline
\end{tabular}




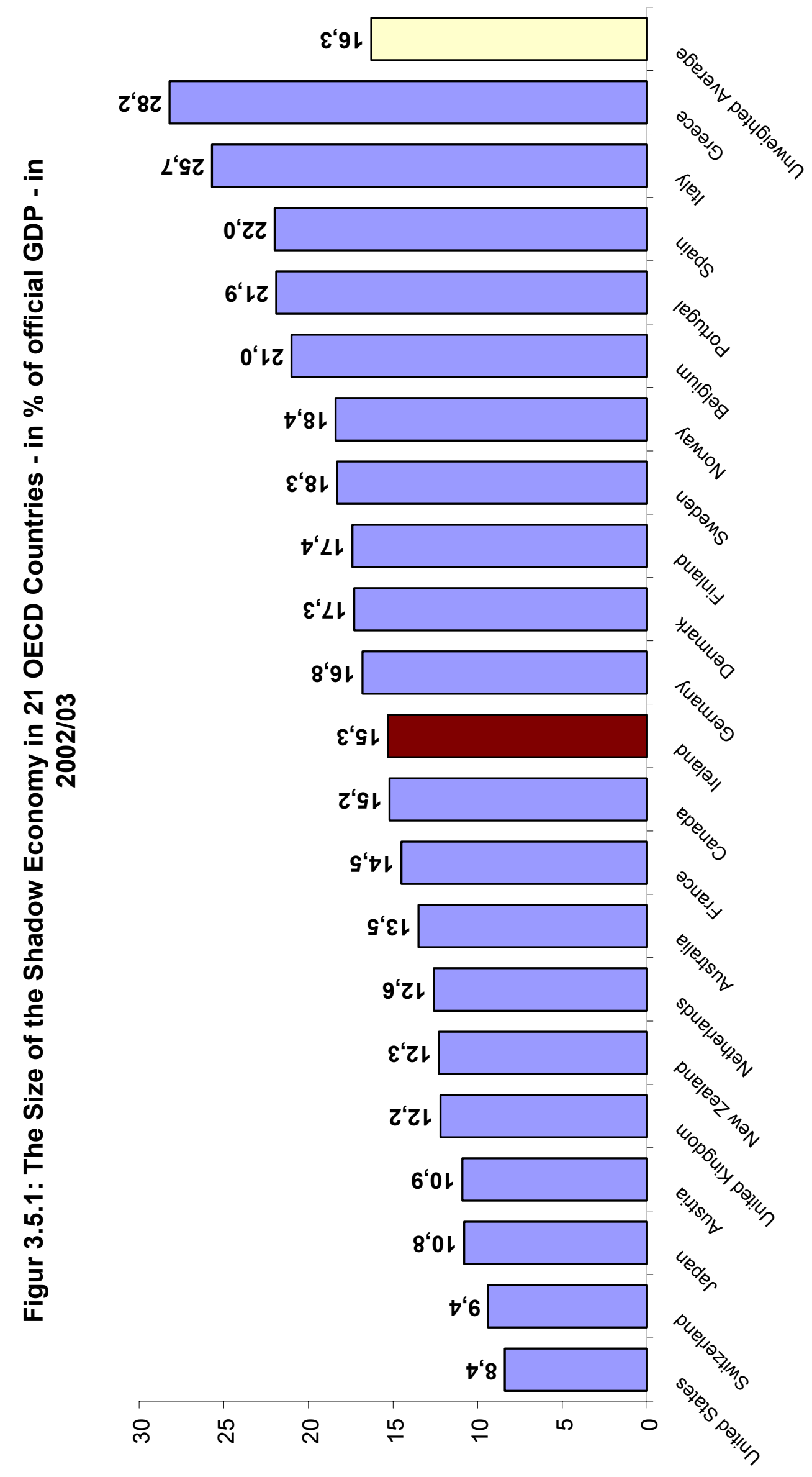




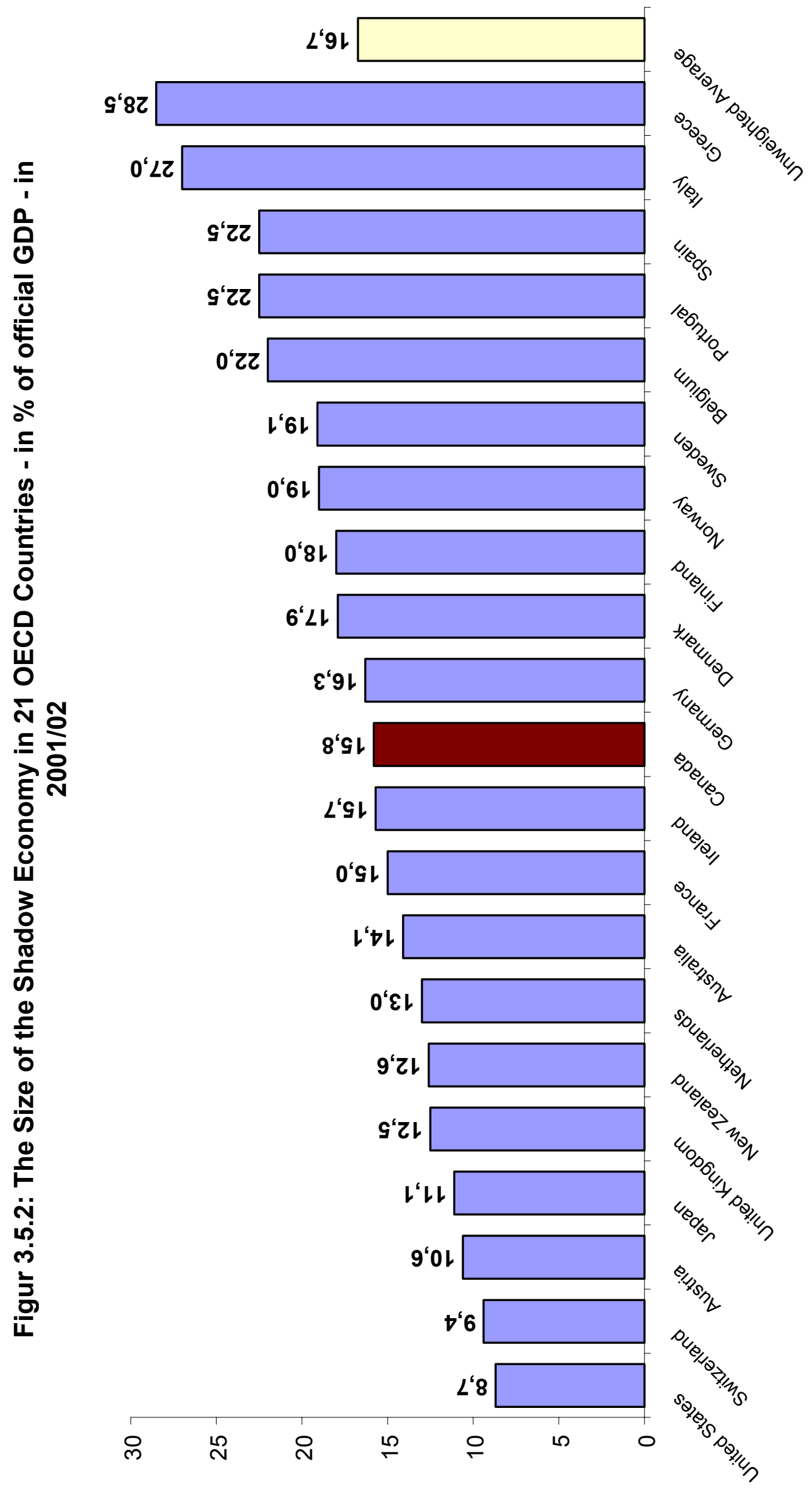




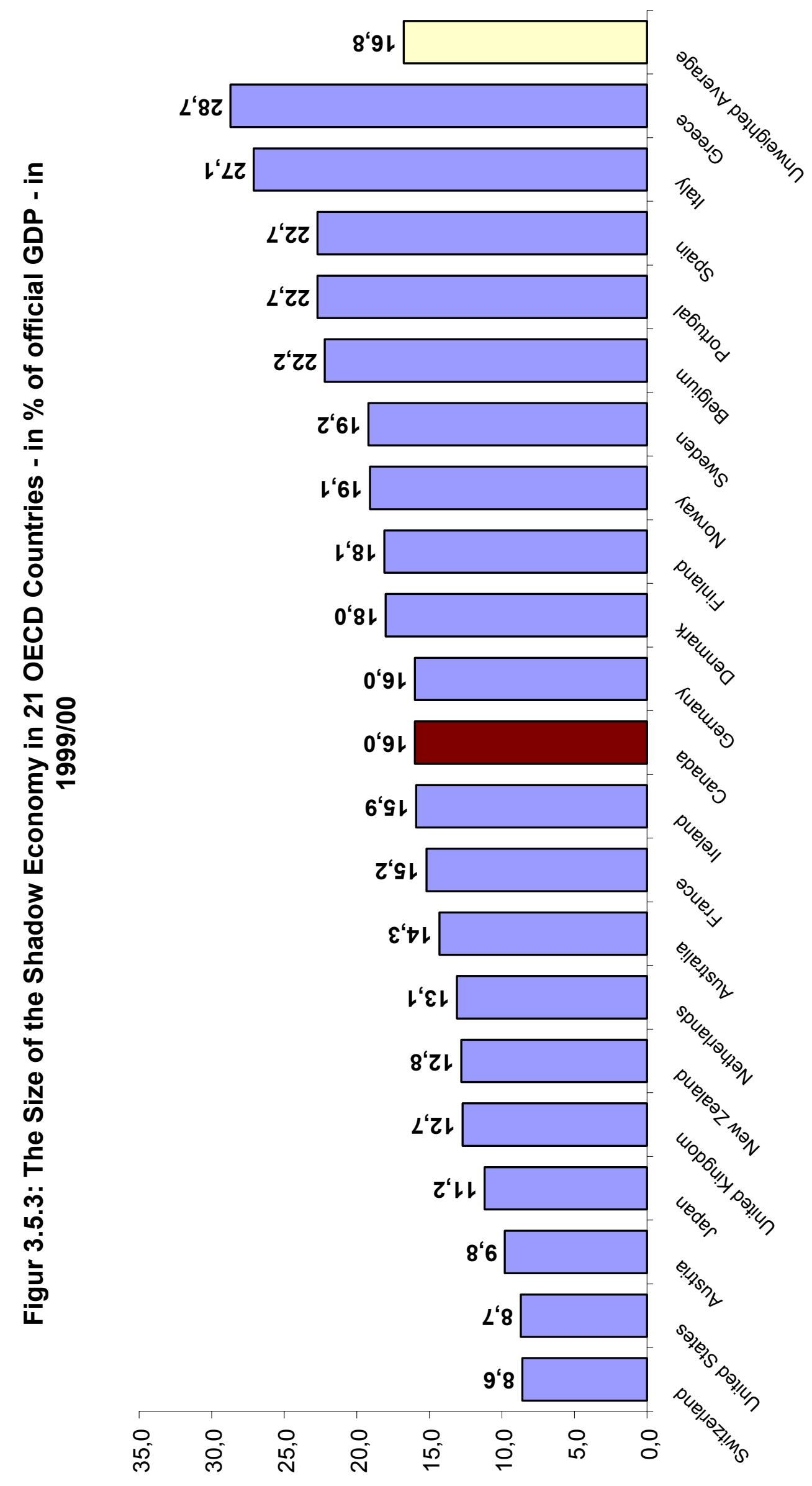


If we first consider again the development of the size and development of the shadow economies of these 21 OECD countries, we realize for the first time that the size of the shadow economy of these 21 OECD countries has decreased over the period 1999/2000 to $2002 / 2003$. The average size of the shadow economy in $1999 / 2000$ of these 21 OECD countries was $16.8 \%$ of official GDP, it decreased to $16.3 \%$ in $2002 / 2003$, a decrease of 0.5 percentage points. If we consider single countries, Greece, Italy and Spain has by far the largest size of the shadow economy in 2002/2003 with $28.2 \%, 25.7 \%$ and $22.0 \%$ of official GDP. The median country is Ireland with $15.3 \%$, surrounded by Germany with $16.8 \%$ and Canada with $15.2 \%$ of official GDP. At the lower end are the United States, Switzerland and Japan with a shadow economy of $8.4 \%, 9.4 \%$ and $10.8 \%$ of official GDP.

\subsubsection{South West Pacific Islands}

The size and development of the shadow economies of 10 South West Pacific islands is presented in table 3.6 and figures 3.6.1-3.6.3.

Table 3.6.: The Size of the Shadow Economy in 10 South West Pacific Islands

\begin{tabular}{|c|c|c|c|c|}
\hline & \multirow[b]{2}{*}{ Country } & \multicolumn{3}{|c|}{$\begin{array}{l}\text { Shadow Economy (in \% of off. GDP) using the } \\
\text { DYMIMIC and Currency Demand Method }\end{array}$} \\
\hline & & $1999 / 00$ & $2001 / 02$ & $2002 / 03$ \\
\hline 1 & Fiji & 33,6 & 34,3 & 35,1 \\
\hline 2 & Kiribati & 34,1 & 35,0 & 35,3 \\
\hline 3 & Maldives & 30,3 & 31,4 & 32,0 \\
\hline 4 & Marshall Islands & 28,1 & 29,0 & 29,6 \\
\hline 5 & Micronesia, Fed. Sts. & 31,3 & 32,1 & 33,2 \\
\hline 6 & Palau & 28,4 & 29,2 & 30,0 \\
\hline 7 & Samoa & 31,4 & 32,6 & 33,5 \\
\hline 8 & Solomon Islands & 33,4 & 34,5 & 35,3 \\
\hline 9 & Tonga & 35,1 & 36,3 & 37,4 \\
\hline 10 & Vanuatu & 30,9 & 31,7 & 32,5 \\
\hline \multicolumn{2}{|c|}{ Unweighted Average } & 31,7 & 32,6 & 33,4 \\
\hline
\end{tabular}




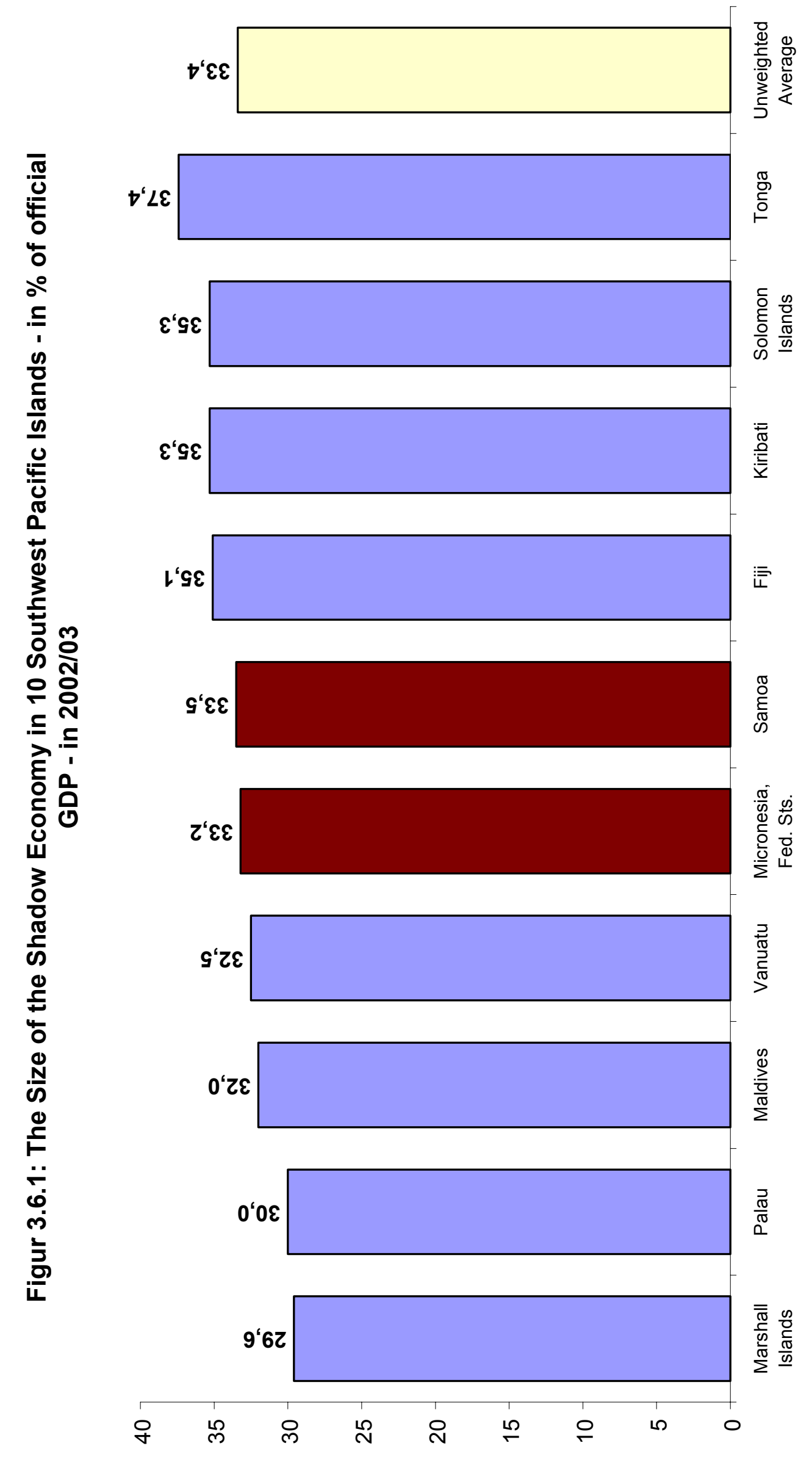




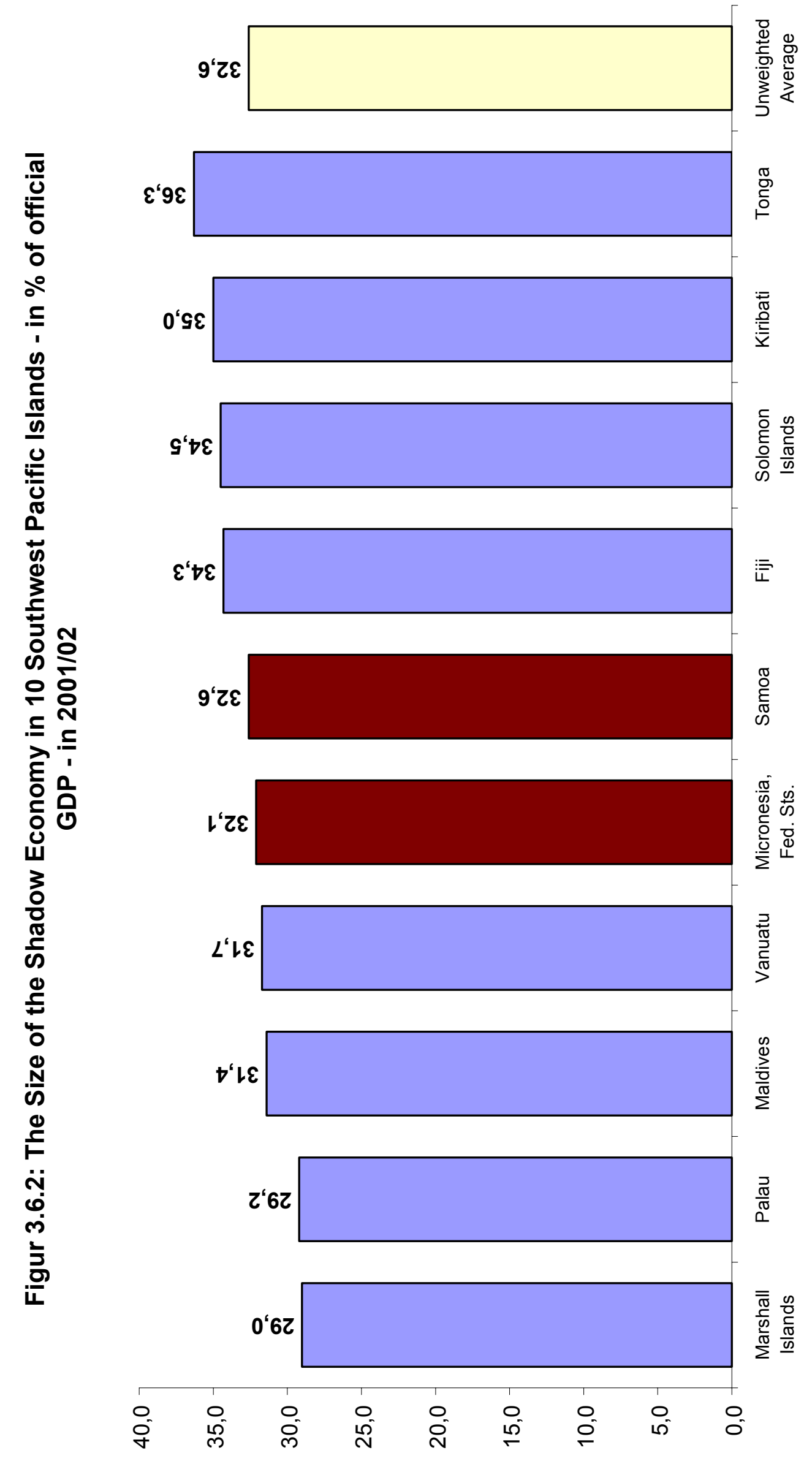




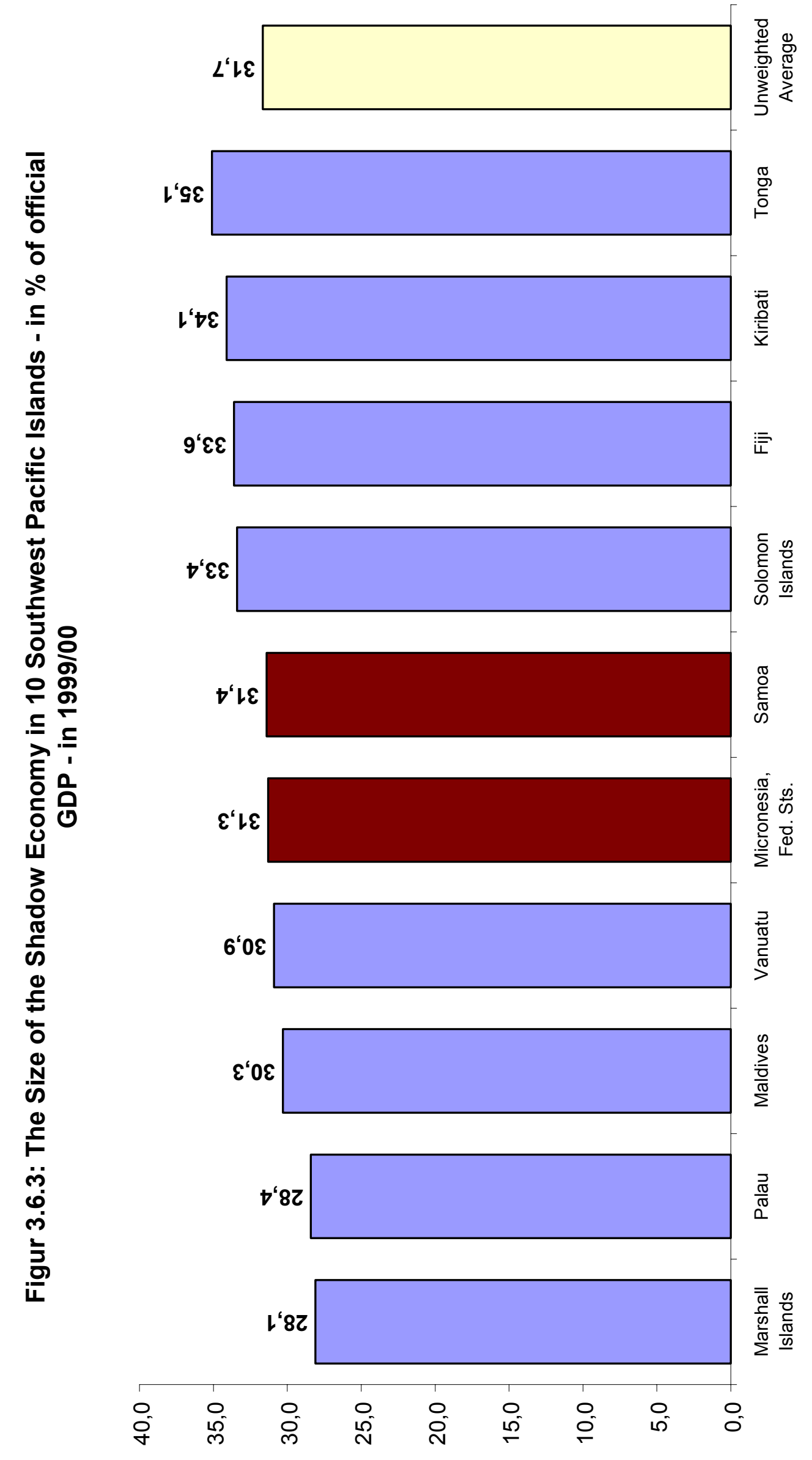


If we again consider first the development over time the average size of the shadow economy of these 10 South West Pacific islands countries, increased from 31.7\% in the year 1999/2000 to $33.4 \%$ in the year $2002 / 2003$, which means an increase of 1.7 percentage points over these four years. The largest size of the shadow economy (the latest estimation period 2002/2003) has Tonga with $37.4 \%$, followed by Solomon Islands with $35.3 \%$ and Kiribati with $35.3 \%$. In the middle field is Micronesia and Samoa with a shadow economy of $33.2 \%$ and $33.5 \%$ of official GDP. The lowest shadow economy have the Marshall Islands and Palau with a shadow economy of $29.6 \%$ and $30.0 \%$.

\subsubsection{Communist Countries}

In this last section the size and development of the shadow economy of 4 communist countries (China, Laos, Mongolia and Vietnam) is presented. The results are shown in table 3.7 and figures 3.7.1-3.7.3.

Table 3.7: The Size of the Shadow Economy in 4 Communist Countries

\begin{tabular}{|c|c|c|c|c|}
\hline \multirow[b]{2}{*}{ No. } & \multirow[b]{2}{*}{ Country } & \multicolumn{3}{|c|}{$\begin{array}{c}\text { Shadow Economy (in \% of off. GDP) using the DYMIMIC and } \\
\text { Currency Demand Method }\end{array}$} \\
\hline & & $1999 / 00$ & $2001 / 02$ & $2002 / 03$ \\
\hline 1 & China & 13,1 & 14,4 & 15,6 \\
\hline 2 & Lao PDR & 30,6 & 31,9 & 33,4 \\
\hline 3 & Mongolia & 18,4 & 19,6 & 20,4 \\
\hline 4 & Vietnam & 15,6 & 16,9 & 17,9 \\
\hline \multicolumn{2}{|c|}{ Unweighted Average } & 19,4 & 20,7 & 21,8 \\
\hline
\end{tabular}



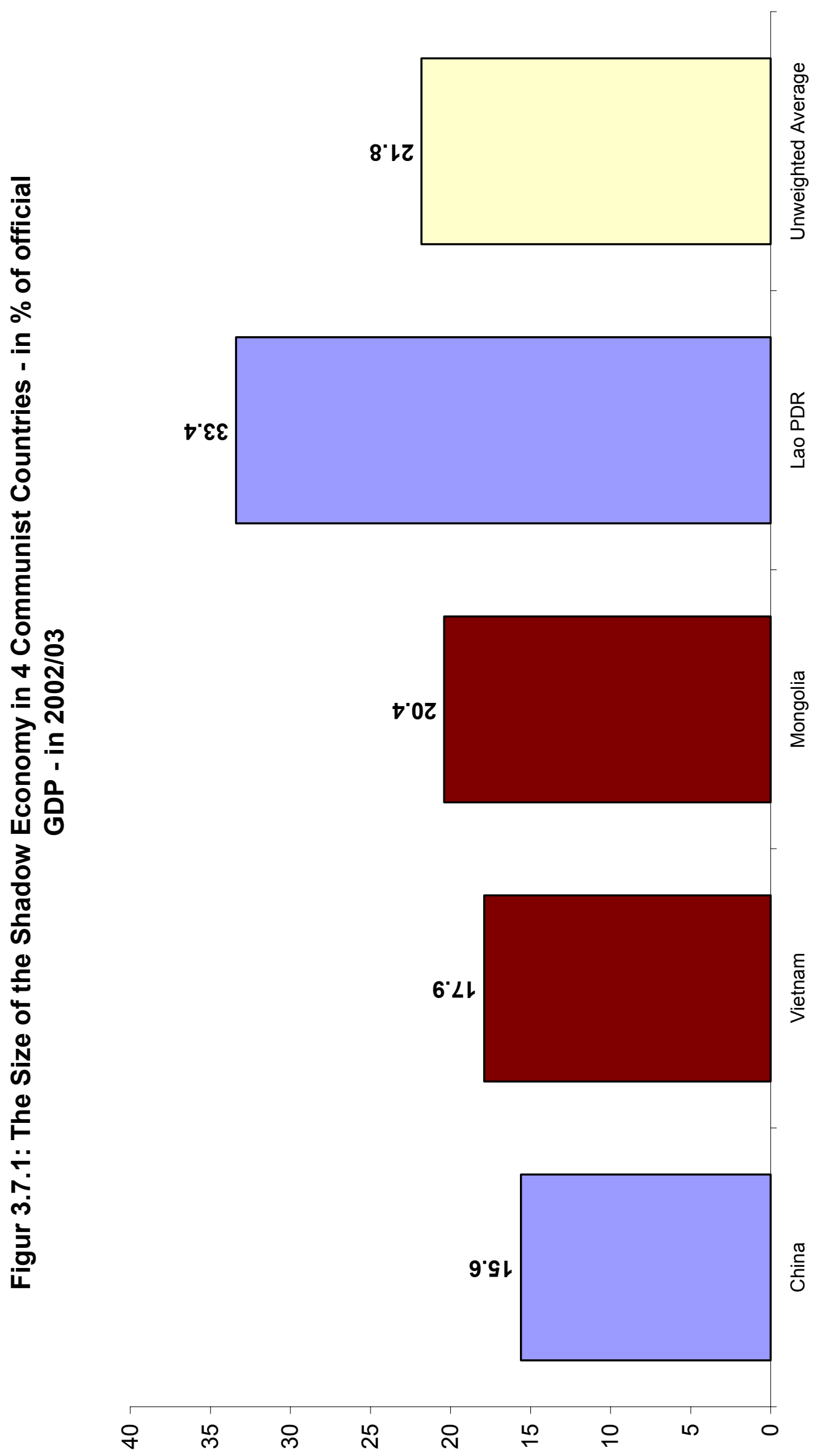

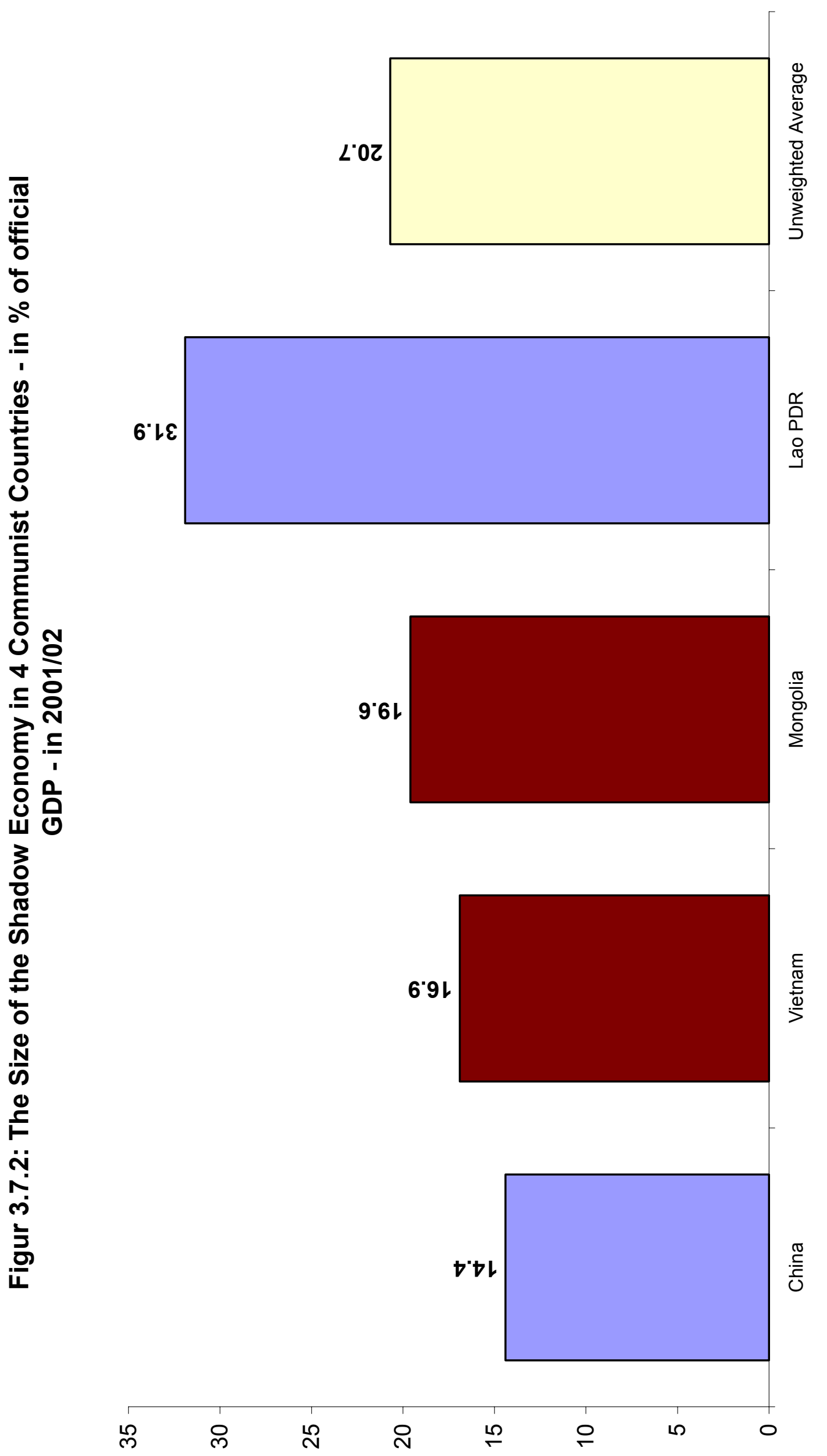


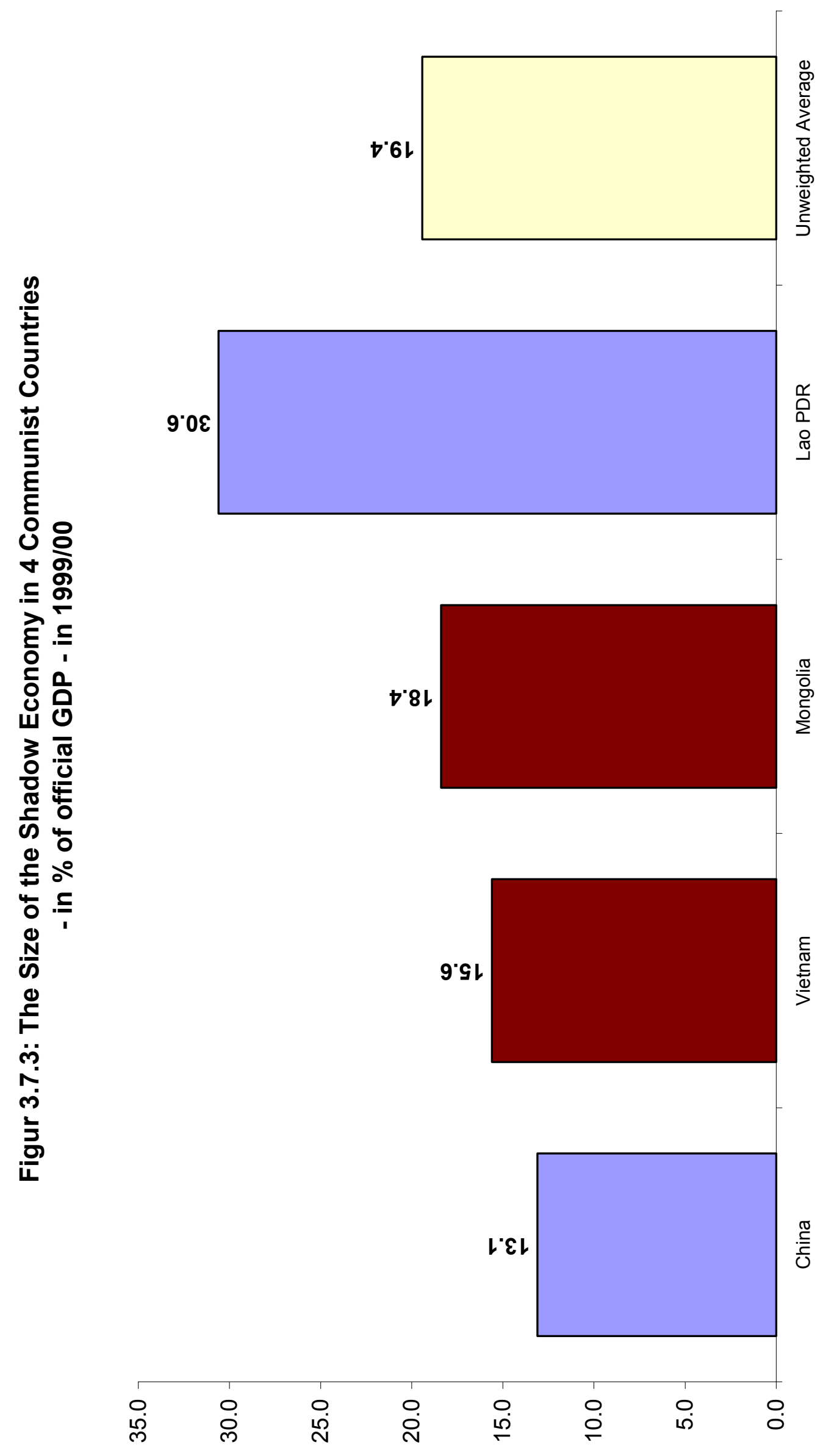


If we again first consider the average development of the size of the shadow economy of these four Communist countries over time, the average size of the shadow economy in 1999/2000 was $19.4 \%$ and increased to $21.8 \%$ in $2002 / 2003$. This is an increase of 2.4 percentage points. Laos has the largest shadow economy with $33.4 \%$ and China the lowest with $15.6 \%$. It should be aware that the shadow economy in these countries, and especially in China, which is partly a market economy and still a planning socialist economy, is difficult to interpret. It should be more seen as a parallel economy, where especially farmers produce additional products to earn some extra money. It is an open question whether the meaning of these shadow economies can be compared to the size of the other ones. That is one reason, why they are shown in this paper in an extra section.

\section{Summary and Conclusions}

There have been many obstacles to overcome to measure the size of the shadow economy and to analyze its consequences on the official economy, but as this paper shows that some progress has been made. I provided estimates of the size of the shadow economies for 145 countries for three periods of time (1999/2000, 2001/2002 and 2002/2003) using the DYMIMIC and the currency demand approach. Hence, some insights can be provided into the size and development of the shadow economy of developing, transition, highly developed OECD, Pacific Islands and Communist countries. ${ }^{14)}$ The first conclusion from these results is that for all countries investigated the shadow economy has reached a remarkably large size; the summarized results are shown in table 4.1.

\footnotetext{
${ }^{14}$ In the appendix some critical discussion of these two methods is given, they have well known weaknesses, compare also Pedersen (2003).
} 
Table 4.1: Average Size of the Shadow Economy for Developing, Transition and OECDCountries in \% of official GDP

\begin{tabular}{|c|c|c|c|}
\hline \multirow{2}{*}{$\frac{\text { Countries/Year }}{\text { Mostly developing countries: }}$} & \multicolumn{3}{|c|}{$\begin{array}{c}\text { Average Size of the Shadow Economy - Value added in \% } \\
\text { of official GDP using DYMIMIC and Currency Demand } \\
\text { method (Number of Countries) }\end{array}$} \\
\hline & $1999 / 2000$ & $2000 / 2001$ & $2002 / 2003$ \\
\hline $\begin{array}{l}\text { Africa } \\
\text { Central and South America } \\
\text { Asia }\end{array}$ & $\begin{array}{l}\mathbf{3 3 . 9} \\
(24) \\
\mathbf{3 4 . 2} \\
(17) \\
\mathbf{2 0 . 9} \\
(25)\end{array}$ & $\begin{array}{c}\mathbf{3 7 . 4} \\
(24) \\
\mathbf{3 7 . 7} \\
(17) \\
\mathbf{2 3 . 4} \\
(25) \\
\end{array}$ & $\begin{array}{l}\mathbf{4 1 . 2} \\
(24) \\
\mathbf{4 1 . 5} \\
(17) \\
\mathbf{2 6 . 3} \\
(25)\end{array}$ \\
\hline Transition countries & $\begin{array}{l}31.5 \\
(23)\end{array}$ & $\begin{array}{l}34.6 \\
(23)\end{array}$ & $\begin{array}{l}37.9 \\
(23)\end{array}$ \\
\hline $\begin{array}{l}\text { Highly developed OECD } \\
\text { Countries }\end{array}$ & $\begin{array}{l}\mathbf{1 3 . 2} \\
(21)\end{array}$ & $\begin{array}{l}\mathbf{1 5 . 7} \\
(21)\end{array}$ & $\begin{array}{l}\mathbf{1 6 . 8} \\
(21)\end{array}$ \\
\hline South Pacific Islands & $\begin{array}{l}31.7 \\
(10)\end{array}$ & $\begin{array}{l}32.6 \\
(10)\end{array}$ & $\begin{array}{l}33.4 \\
(10)\end{array}$ \\
\hline Communist Countries & $\begin{array}{c}19.4 \\
(4)\end{array}$ & $\begin{array}{c}20.7 \\
(4)\end{array}$ & $\begin{array}{c}21.8 \\
(4)\end{array}$ \\
\hline $\begin{array}{l}\text { Unweighted Average over } \\
145 \text { Countries }\end{array}$ & 33.6 & 34.5 & 35.2 \\
\hline
\end{tabular}

Source: Own calculations.

The second conclusion is, shadow economies are a complex phenomenon, present to an important extent in all type of economies (developing, transition and developed). People engage in shadow economic activity for a variety of reasons, among most important, of which we can count are government actions, most notable taxation and regulation. With these two insights/conclusions goes a third, no less important one: a government aiming to decrease shadow economic activity has to first and foremost analyze the complex relationships between the official and shadow economy - and even more important - among consequences of its own policy decisions. 


\section{Appendix: Methods to Estimate the Size of the Shadow Economy}

As has already been mentioned in chapters 2 and 3 estimating the size of a shadow economy is a difficult and challenging task. In this appendix I give a short but comprehensive overview on the various procedures to estimate the size of a shadow economy. Three different types of methods are most widely used, and each is briefly discussed as well as critically evaluated.

\subsection{Direct Approaches}

These are micro approaches that employ either well designed surveys and samples based on voluntary replies or tax auditing and other compliance methods. Sample surveys designed to estimate the shadow economy are widely used in a number of countries ${ }^{15)}$. The main disadvantage of this method is that it presents the flaws of all surveys. For example, the average precision and results depend greatly on the respondent's willingness to cooperate, it is difficult to asses the amount of undeclared work from a direct questionnaire, most interviewers hesitate to confess a fraudulent behavior, and responses are of uncertain reliability, which makes it difficult to calculate a real estimate (in monetary terms) of the extend of undeclared work. The main advantage of this method lies in the detailed information about the structure of the shadow economy, but the results from these kinds of surveys are very sensitive to the way the questionnaire is formulated ${ }^{16)}$.

Estimates of the shadow economy can also be based on the discrepancy between income declared for tax purposes and that measured by selective checks. Fiscal auditing programs have been particularly effective in this regard. Since these programs are designed to measure the amount of undeclared taxable income, they may also be used to calculate the shadow

\footnotetext{
${ }^{15)}$ The direct method of voluntary sample surveys has been extensively used for Norway by Isachsen, Klovland and Strom (1982), and Isachsen and Strom (1985). For Denmark this method is used by Mogensen et. al. (1995) in which they report „estimates“ of the shadow economy of 2.7 percent of GDP for 1989, of 4.2 percent of GDP for 1991, of 3.0 percent of GDP for 1993 and of 3.1 percent of GDP for 1994. In Pedersen (2003) estimates of the Danish shadow economy contain the years 1995 with $3.1 \%$ up to 2001 with $3.8 \%$.

16) The advantages and disadvantages of this method are extensively dealt by Pedersen (2003) and Mogensen et. al (1995) in their excellent and very carefully done investigations.
} 
economy. ${ }^{17)}$ However, a number of difficulties beset this approach. First, using tax compliance data are equivalent to using a (possibly biased) sample of the population. In general, the selection of tax payers for tax audit is not random but based on properties of submitted ( $\operatorname{tax})$ returns that indicate a certain likelihood of (tax) fraud. Consequently, such a sample is not a random one of the whole population, and estimates of the shadow based upon a biased sample may not be accurate. Second estimates based on tax audits reflect only that portion of shadow economy income that the authorities succeed in discovering, and this is likely to be only a fraction of hidden income.

A further disadvantage of these two direct methods (surveys and tax auditing) is that they lead only to point estimates. Moreover, it is unlikely that they capture all „shadow“ activities, so they can be seen as providing lower bound estimates. They are unable to provide estimates of the development and growth of the shadow economy over a longer period of time. As already argued, they have, however at least one considerable advantage - they can provide detailed information about shadow economy activities and the structure and composition of those who work in the shadow economy.

\subsection{Indirect Approaches}

These approaches, which are also called ,indicator“ approaches, are mostly macroeconomic ones and use various economic and other indicators that contain information about the development of the shadow economy (over time). Currently there are five indicators that leave some „traces“ of the shadow economy.

\subsubsection{The Discrepancy between National Expenditure and Income Statistics}

This approach is based on discrepancies between income and expenditure statistics. In national accounting the income measure of GNP should be equal to the expenditure measure of GNP. Thus, if an independent estimate of the expenditure site of the national accounts is available, the gap between the expenditure measure and the income measure can be used as an indicator of the extent of the black economy. ${ }^{18)}$ Since national accounts statisticians are

\footnotetext{
${ }^{17)}$ In the United States, IRS (1979, 1983), Simon and Witte (1982), Witte (1987), Clotefelter (1983), and Feige (1986). For a more detailed discussion, see Dallago (1990) and Thomas (1992).

18) See, e.g., Franz (1983) for Austria; MacAfee (1980) O’Higgins (1989) and Smith (1985), for Great Britain;
} 
anxious to minimize this discrepancy, the initial discrepancy or first estimate, rather than the published discrepancy should be employed as an estimate of the shadow economy. If all the components of the expenditure site are measured without error, then this approach would indeed yield a good estimate of the scale of the shadow economy. Unfortunately, however, this is not the case. Instead, the discrepancy reflects all omissions and errors everywhere in the national accounts statistics as well as the shadow economy activity. These estimates may therefore be very crude and of questionable reliability. ${ }^{19)}$

\subsubsection{The Discrepancy between the Official and Actual Labor Force}

A decline in participation of the labor force in the official economy can be seen as an indication of increased activity in the shadow economy. If total labor force participation is assumed to be constant, than a decreasing official rate of participation can be seen as an indicator of an increase in the activities in the shadow economy, ceteris paribus. ${ }^{20)}$ One weakness of this method is that differences in the rate of participation may also have other causes. Also, people can work in the shadow economy and have a job in the „official' economy. Therefore such estimates may be viewed as weak indicators of the size and development of the shadow economy.

\subsubsection{The Transactions Approach}

This approach has been most fully developed by Feige. ${ }^{21)}$ It is based upon the assumption, that there is a constant relation over time between the volume of transaction and official GNP, as summarized by the well-known Fisherian quantity equation, or $M^{*} V=p^{*} T$ (with $M=$ money, $\mathrm{V}=$ velocity, $\mathrm{p}=$ prices, and $\mathrm{T}=$ total transactions). Assumptions also have to be made about the velocity of money and about the relationships between the value of total transactions $\left(\mathrm{p}^{*} \mathrm{~T}\right)$ and total $(=$ official + unofficial) nominal GNP. Relating total nominal GNP to total transactions, the GNP of the shadow economy can be calculated by subtracting

Petersen (1982) and Del Boca (1981) for Germany; Park (1979) for the United States. For a critical survey, see Thomas (1992).

19) A related approach is pursued by Pissarides and Weber (1988), who use micro data from household budget surveys to estimate the extend of income understatement by self-employed.

${ }^{20)}$ Such studies have been made for Italy, see e.g., Contini (1981) and Del Boca (1981); for the United States, see O’Neill (1983), for a critical survey, see again Thomas (1992).

21) For an extended description of this approach, see Feige (1996); for a further application for the Netherlands, Boeschoten and Fase (1984), and for Germany, Langfeldt (1984). 
the official GNP from total nominal GNP. However, to derive figures for the shadow economy, one must also assume a base year in which there is no shadow economy and therefore the ratio of $\mathrm{p}^{*} \mathrm{~T}$ to total nominal (official = total) GNP was ,normal“ and would have been constant over time, if there had been no shadow economy.

This method, too, has several weaknesses, such as the required assumptions of a base year with no shadow economy, and of a „normal“ ratio of transactions to nominal GNP. Moreover, to obtain reliable shadow economy estimates, precise figures of the total volume of transactions should be available, and this availability might be especially difficult to achieve for cash transactions, because they depend, among other factors, on the durability of bank notes in terms of the quality of the papers on which they are printed. ${ }^{22)}$ Also, the assumption is made that all variations in the ratio between the total value of transaction and the officially measured GNP are due to the shadow economy. This means that a considerable amount of data is required in order to eliminate financial transactions from "pure" cross payments, which are legal and have nothing to do with the shadow economy. In general, although this approach is theoretically attractive, the empirical requirements necessary to obtain reliable estimates are so difficult to fulfill, that its application may lead to doubtful results.

\subsubsection{The Currency Demand Approach}

The currency demand approach was first used by Cagan (1958), who calculated a correlation of the currency demand and the tax pressure (as one cause of the shadow economy) for the United States over the period 1919 to 1955. 20 years later, Gutmann (1977) used the same approach but without any statistical procedures. Cagan's approach was further developed by Tanzi (1980, 1983), who econometrically estimated a currency demand function for the United States for the period 1929 to 1980 in order to calculate the shadow economy. His approach assumes that shadow (or hidden) transactions are undertaken in the form of cash payments, so as to leave no observable traces for the authorities. An increase in the size of the shadow economy will therefore increase the demand for currency. To isolate the resulting „excess" demand for currency, an equation for currency demand is econometrically estimated over time. All conventional possible factors, such as the development of income, payment habits, interest rates, and so on, are controlled for. Additionally, such variables as the direct

\footnotetext{
${ }^{22)}$ For a detailed criticism of the transaction approach see Boeschoten and Fase (1984), Frey and Pommerehne (1984), Kirchgaessner (1984), Tanzi (1982a,b, 1986), Dallago (1990), Thomas (1986, 1992, 1999) and Giles
} 
and indirect tax burden, government regulation and the complexity of the tax system, which are assumed to be the major factors causing people to work in the shadow economy, are included in the estimation equation. The basic regression equation for the currency demand, proposed by Tanzi (1983), is the following:

$\ln \left(\mathrm{C} / \mathrm{M}_{2}\right)_{\mathrm{t}}=\beta_{\mathrm{O}}+\beta_{1} \ln (1+\mathrm{TW})_{\mathrm{t}}+\beta_{2} \ln (\mathrm{WS} / \mathrm{Y})_{\mathrm{t}}+\beta_{3} \ln \mathrm{R}_{\mathrm{t}}+\beta_{4} \ln (\mathrm{Y} / \mathrm{N})_{\mathrm{t}}+\mathrm{u}_{\mathrm{t}}$

with $\beta_{1}>0, \beta_{2}>0, \beta_{3}<0, \beta_{4}>0$

where

In denotes natural logarithms,

$\mathrm{C} / \mathrm{M}_{2}$ is the ratio of cash holdings to current and deposit accounts,

TW is a weighted average tax rate (to proxy changes in the size of the shadow economy),

WS / Y is a proportion of wages and salaries in national income (to capture changing payment and money holding patterns),

$\mathrm{R}$ is the interest paid on savings deposits (to capture the opportunity cost of holding cash) and $\mathrm{Y} / \mathrm{N}$ is the per capita income. ${ }^{23)}$

Any „excess“ increase in currency, or the amount unexplained by the conventional or normal factors (mentioned above) is then attributed to the rising tax burden and the other reasons leading people to work in the shadow economy. Figures for the size and development of the shadow economy can be calculated in a first step by comparing the difference between the development of currency when the direct and indirect tax burden (and government regulations) are held at its lowest value, and the development of currency with the current (much higher) burden of taxation and government regulations. Assuming in a second step the same income velocity for currency used in the shadow economy as for legal M1 in the official economy, the size of the shadow can be computed and compared to the official GDP.

The currency demand approach is one of the most commonly used approaches. It has been applied to many OECD countries, ${ }^{24)}$ but has nevertheless been criticized on various grounds. ${ }^{25)}$ The most commonly raised objections to this method are several:

(1999a).

23) The estimation of such a currency demand equation has been criticized by Thomas (1999) but part of this criticism has been considered by the work of Giles (1999a,b) and Bhattacharyya (1999), who both use the latest econometric technics.

${ }^{24)}$ See Karmann (1986 and 1990), Schneider (1997, 1998a), Johnson, Kaufmann and Zoido-Lobatón (1998a), and Williams and Windebank (1995).

${ }^{25}$ See Thomas (1992, 1999), Feige (1986), Pozo (1996), Pedersen (2003) and Ahumada, Alvareda, Canavese A. 
(i) Not all transactions in the shadow economy are paid in cash. Isachsen and Strom (1985) used the survey method to find out that in Norway, in 1980, roughly 80 percent of all transactions in the hidden sector were paid in cash. The size of the total shadow economy (including barter) may thus be even larger than previously estimated.

(ii) Most studies consider only one particular factor, the tax burden, as a cause of the shadow economy. But others (such as the impact of regulation, taxpayers' attitudes toward the state, „tax morality“ and so on) are not considered, because reliable data for most countries is not available. If, as seems likely, these other factors also have an impact on the extent of the hidden economy, it might again be higher than reported in most studies. ${ }^{26)}$

(iii) As discussed by Garcia (1978), Park (1979), and Feige (1996), increases in currency demand deposits are due largely to a slowdown in demand deposits rather than to an increase in currency caused by activities in the shadow economy, at least in the case of the United States.

(iv) Blades (1982) and Feige (1986, 1996), criticize Tanzi's studies on the grounds that the US dollar is used as an international currency. Instead, Tanzi should have considered (and controlled for) the presence of US dollars, which are used as an international currency and held in cash abroad. ${ }^{27)}$ Moreover, Frey and Pommerehne (1984) and Thomas $(1986,1992$, 1999) claim that Tanzi's parameter estimates are not very stable. $^{28)}$

(v) Most studies assume the same velocity of money in both types of economies. As argued by Hill and Kabir (1996) for Canada and by Klovland (1984) for the

\footnotetext{
and P. Canavese (2004).

26) One (weak) justification for the only use of the tax variable is that this variable has by far the strongest impact on the size of the shadow economy in the studies known to the authors. The only exception is the study by Frey and Weck-Hannemann (1984) where the variable „tax immorality“ has a quantitatively larger and statistically stronger influence than the direct tax share in the model approach. In the study of Pommerehne and Schneider (1985), for the U.S., besides various tax measures, data for regulation, tax immorality, minimum wage rates are available, the tax variable has a dominating influence and contributes roughly 60-70 percent to the size of the shadow economy. See also Zilberfarb (1986).

${ }^{27)}$ In another study by Tanzi (1982, esp. pp. 110-113) he explicitly deals with this criticism. A very careful investigation of the amount of US-\$ used abroad and the US currency used in the shadow economy and to "classical" crime activities has been undertaken by Rogoff (1998), who concludes that large denomination bills are major driving force for the growth of the shadow economy and classical crime activities due largely to reduced transactions costs.

28) However in studies for European countries Kirchgaessner $(1983,1984)$ and Schneider (1986) reach the conclusion that the estimation results for Germany, Denmark, Norway and Sweden are quite robust when using the currency demand method. Hill and Kabir (1996) find for Canada that the rise of the shadow economy varies with respect to the tax variable used; they conclude ,when the theoretically best tax rates are selected and a range of plausible velocity values is used, this method estimates underground economic growth between 1964 and 1995 at between 3 and 11 percent of GDP.“ (Hill and Kabir [1996, p. 1553]).
} 
Scandinavian countries, there is already considerable uncertainty about the velocity of money in the official economy, and the velocity of money in the hidden sector is even more difficult to estimate. Without knowledge about the velocity of currency in the shadow economy, one has to accept the assumption of an „equal“ money velocity in both sectors.

(vi) Ahumada, Alvaredo, Canavese A. and P. Canavese (2004) show, that the currency approach together with the assumption of equal income velocity of money in both, the reported and the hidden transaction is only correct, if the income elasticity is 1 . As this is for most countries not the case, the calculation has to be corrected.

(vii) Finally, the assumption of no shadow economy in a base year is open to criticism. Relaxing this assumption would again imply an upward adjustment of the size of the shadow economy.

\subsubsection{The Physical Input (Electricity Consumption) Method}

\section{(1) The Kaufmann - Kaliberda Method ${ }^{29)}$}

To measure overall (official and unofficial) economic activity in an economy, Kaufmann and Kaliberda (1996) assume that electric-power consumption is regarded as the single best physical indicator of overall (or official plus unofficial) economic activity. Now, overall economic activity and electricity consumption have been empirically observed throughout the world to move in lockstep with an electricity to GDP elasticity usually close to one. This means, that the growth of total electricity consumption is an indicator for growth of overall (official and unofficial) GDP. By having this proxy measurement for the overall economy and then subtracting from this overall measure the estimates of official GDP, Kaufmann and Kaliberda (1996) derive an estimate of unofficial GDP. This method is very simple and appealing. However, it can also be criticized on various grounds:

(i) Not all shadow economy activities require a considerable amount of electricity (e.g. personal services), and other energy sources can be used (gas, oil, coal, etc.). Only a part of the shadow economy will be captured.

\footnotetext{
${ }^{29)}$ This method was used earlier by Lizzeri (1979), Del Boca and Forte (1982), and then was used much later by Portes (1996), Kaufmann and Kaliberda (1996), Johnson, Kaufmann and Shleifer (1997). For a critique see Lackó (1998).
} 
(ii) Over time, there has been considerable technical progress, so that both the production and use of electricity are more efficient than in the past, and this will apply in both official and unofficial uses.

(iii) There may be considerable differences or changes in the elasticity of electricity/GDP across countries and over time. ${ }^{30)}$

\section{(2) The Lackó Method}

Lackó $(1996,1998,1999,2000)$ assumes that a certain part of the shadow economy is associated with the household consumption of electricity. This part comprises the so-called household production, do-it-yourself activities, and other non registered production and services. Lackó further assumes that in countries where the portion of the shadow economy associated with the household electricity consumption is high, the rest of the hidden economy (or the part Lackó cannot measure) will also be high. Lackó (1996, pp.19 ff.) assumes that in each country a part of the household consumption of electricity is used in the shadow economy.

Lackó's approach (1998, p.133) can be described by the following two equations:

$\ln \mathrm{E}_{\mathrm{i}}=\alpha_{1} \ln \mathrm{C}_{\mathrm{i}}+\alpha_{2} \ln \mathrm{PR}_{\mathrm{i}}+\alpha_{3} \mathrm{G}_{\mathrm{i}}+\alpha_{4} \mathrm{Q}_{\mathrm{i}}+\alpha_{5} \mathrm{H}_{\mathrm{i}}+\mathrm{u}_{\mathrm{i}}$

with $\quad \alpha_{1}>0, \alpha_{2}<0, \alpha_{3}>0, \alpha_{4}<0, \alpha_{5}>0$

$\mathrm{H}_{\mathrm{i}} \quad=\beta_{1} \mathrm{~T}_{\mathrm{i}}+\beta_{2}\left(\mathrm{~S}_{\mathrm{i}}-\mathrm{T}_{\mathrm{i}}\right)+\beta_{3} \mathrm{D}_{\mathrm{i}}$

with $\beta_{1}>0, \beta_{2}<0, \beta_{3}>0$

where

i: the number assigned to the country,

$\mathrm{E}_{\mathrm{i}}$ : per capita household electricity consumption in country $\mathrm{i}$ in Mtoe,

$\mathrm{C}_{\mathrm{i}}$ : per capita real consumption of households without the consumption of electricity in country $\mathrm{i}$ in US dollars (at purchasing power parity),

$\mathrm{PR}_{\mathrm{i}}$ : the real price of consumption of $1 \mathrm{kWh}$ of residential electricity in US dollars (at purchasing power parity),

$\mathrm{G}_{\mathrm{i}}$ : the relative frequency of months with the need of heating in houses in country $i$,

$Q_{i}$ : the ratio of energy sources other than electricity energy to all energy sources in household energy consumption,

$\mathrm{H}_{\mathrm{i}}$ : the per capita output of the hidden economy,

\footnotetext{
${ }^{30)}$ Johnson, Kaufmann and Shleifer (1997) make an attempt to adjust for changes in the elasticity of electricity/GDP.
} 
$\mathrm{T}_{\mathrm{i}}$ : the ratio of the sum of paid personal income, corporate profit and taxes on goods and services to GDP,

$\mathrm{S}_{\mathrm{i}}$ : the ratio of public social welfare expenditures to GDP, and

$\mathrm{D}_{\mathrm{i}}$ : the sum on number of dependants over 14 years and of inactive earners, both per 100 active earners.

In a cross country study, she econometrically estimates equation (1) substituting $\mathrm{H}_{\mathrm{i}}$ by equation (2). The econometric estimation results can then be used to establish an ordering of the countries with respect to electricity use in their respective shadow economies. For the calculation of the actual size (value added) of the shadow economy, Lackó further must know how much GDP is produced by one unit of electricity in the shadow economy of each country. Since these data are not known, she takes the result of one of the known shadow economy estimations, that were carried out for a market economy with another approach for the early 1990s, and she applies this proportion to the other countries. Lackó used the shadow economy of the United States as such a base (the shadow economy value of $10.5 \%$ of GDP taken from Morris(1993)), and then she calculates the size of the shadow economy for other countries. Lackó's method is also open to criticism:

(i) Not all shadow economy activities require a considerable amount of electricity and other energy sources can be used.

(ii) Shadow economy activities do not take place only in the household sector.

(iii) It is doubtful whether the ratio of social welfare expenditures can be used as the explanatory factor for the shadow economy, especially in transition and developing countries.

It is questionable which is the most reliable base value of the shadow economy in order to calculate the size of the shadow economy for all other countries, especially, for the transition and developing countries.

\subsection{The model approach ${ }^{31}$}

All methods described so far that are designed to estimate the size and development of the

\footnotetext{
31) This summary is derived from a longer study by Aigner, Schneider, and Ghosh (1988, p. 303), applying this approach for the United States over time; for Germany this approach has been applied by Karmann (1986 and 1990). The pioneers of this approach are Weck (1983), Frey and Weck-Hannemann (1984), who applied this approach to cross-section data from the 24 OECD countries for various years. Before turning to this approach they developed the concept of ,soft modeling“ (Frey, Weck, and Pommerehne (1982), Frey and Weck (1983a and 1983b)), an approach which has been used to provide a ranking of the relative size of the shadow economy
} 
shadow economy consider just one indicator that "must" capture all effects of the shadow economy. However, it is obvious that shadow economy effects show up simultaneously in the production, labor, and money markets. An even more important critique is that the causes that determine the size of the shadow economy are taken into account only in some of the monetary approach studies that usually consider one cause, the burden of taxation. The model approach explicitly considers multiple causes leading to the existence and growth of the shadow economy, as well as the multiple effects of the shadow economy over time.

The empirical method used is quite different from those used so far. It is based on the statistical theory of unobserved variables, which considers multiple causes and multiple indicators of the phenomenon to be measured. For the estimation, a factor-analytic approach is used to measure the hidden economy as an unobserved variable over time. The unknown coefficients are estimated in a set of structural equations within which the "unobserved" variable cannot be measured directly. The DYMIMIC (dynamic multiple-indicators multiplecauses) model consists in general of two parts, with the measurement model linking the unobserved variables to observed indicators. ${ }^{32)}$ The structural equations model specifies causal relationships among the unobserved variables. In this case, there is one unobserved variable, or the size of the shadow economy; this is assumed to be influenced by a set of indicators for the shadow economy's size, thus capturing the structural dependence of the shadow economy on variables that may be useful in predicting its movement and size in the future. The interaction over time between the causes $Z_{i t}(i=1,2, \ldots, k)$ the size of the shadow economy $\mathrm{X}_{\mathrm{t}}$, in time $\mathrm{t}$ and the indicators $\mathrm{Y}_{\mathrm{jt}}(\mathrm{j}=1,2, \ldots, \mathrm{p})$ is shown in Figure 6.1.

\footnotetext{
in different countries.

${ }^{32}$ One of the latest paper dealing extensively with the DYMIMIC approach, its development and its weaknesses is from Del'Anno (2003) as well as the excellent study by Giles and Tedds (2002).
} 


\section{Figure 6.1: Development of the shadow economy over time.}

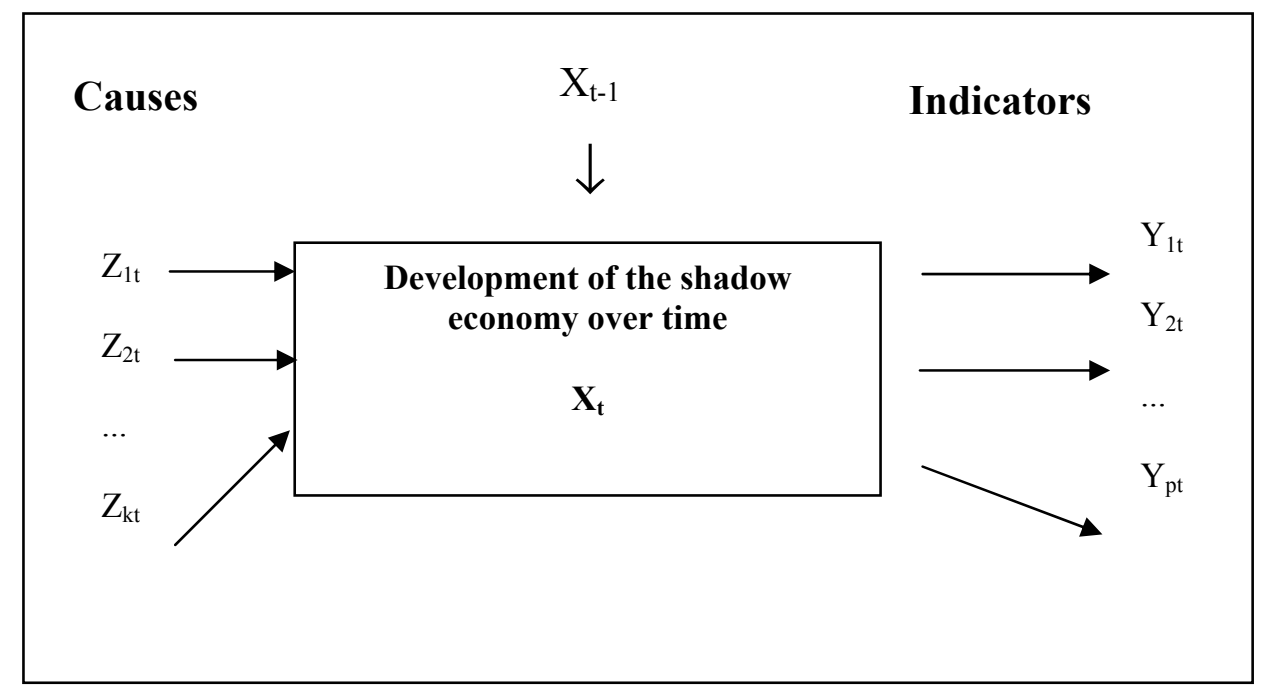

There is a large body of literature ${ }^{33)}$ on the possible causes and indicators of the shadow economy, in which the following three types of causes are distinguished:

\section{Causes}

(i) The burden of direct and indirect taxation, both actual and perceived. A rising burden of taxation provides a strong incentive to work in the shadow economy.

(ii) The burden of regulation as proxy for all other state activities. It is assumed that increases in the burden of regulation give a strong incentive to enter the shadow economy.

(iii) The „tax morality“ (citizens' attitudes toward the state), which describes the readiness of individuals (at least partly) to leave their official occupations and enter the shadow economy: it is assumed that a declining tax morality tends to increase the size of the shadow economy. ${ }^{34)}$

\section{Indicators}

A change in the size of the shadow economy may be reflected in the following indicators:

(i) Development of monetary indicators. If activities in the shadow economy rise, additional monetary transactions are required.

\footnotetext{
${ }^{33)}$ Thomas (1992); Schneider (1994a, 1997, 2003, 2005); Pozo (1996); Johnson, Kaufmann and Zoido-Lobatón (1998a, 1998b); Giles (1997a, 1997b, 1999a, 1999b, 1999c); Giles and Tedds (2002), Giles, Tedds and Werkneh (2002), Del'Anno (2003) and Del'Anno and Schneider (2004).

${ }^{34)}$ When applying this approach for European countries, Frey and Weck-Hannemann (1984) had the difficulty in obtaining reliable data for the cause series, besides the ones of direct and indirect tax burden. Hence, their study was criticized by Helberger and Knepel (1988), who argue that the results were unstable with respect to changing variables in the model and over the years.
} 
(ii) Development of the labor market. Increasing participation of workers in the hidden sector results in a decrease in participation in the official economy. Similarly, increased activities in the hidden sector may be expected to be reflected in shorter working hours in the official economy.

(iii) Development of the production market. An increase in the shadow economy means that inputs (especially labor) move out of the official economy (at least partly), and this displacement might have a depressing effect on the official growth rate of the economy.

The latest use of the model approach has been undertaken by Giles (1999a, 1999b, 1999c) and by Giles, Tedds and Werkneh (2002), Giles and Tedds (2002), Chatterjee, Chaudhury and Schneider (2002) and Bajada and Schneider (2003). They basically estimates a comprehensive (dynamic) MIMIC model to get a time serious index of the hidden/measured output of New Zealand, Canada, India or Australia, and then estimate a separate "cashdemand model" to obtain a benchmark for converting this index into percentage units. Unlike earlier empirical studies of the hidden economy, they paid proper attention to the nonstationary, and possible co-integration of time serious data in both models. Again this DYMIMIC model treats hidden output as a latent variable, and uses several (measurable) causal variables and indicator variables. The former include measures of the average and marginal tax rates, inflation, real income and the degree of regulation in the economy. The latter include changes in the (male) labor force participation rate and in the cash/money supply ratio. In their cash-demand equation they allow for different velocities of currency circulation in the hidden and recorded economies. Their cash-demand equation is not used as an input to determine the variation in the hidden economy over time - it is used only to obtain the long-run average value of hidden/measured output, so that the index for this ratio predicted by the DYMIMIC model can be used to calculate a level and the percentage units of the shadow economy. Overall, this latest combination of the currency demand and DYMIMIC approach clearly shows that some progress in the estimation technique of the shadow economy has been achieved and a number of critical points have been overcome.

However, also against this method objections can be raised, which are

(1) instability in the estimated coefficients with respect to sample size changes,

(2) instability in the estimated coefficients with respect to alternative specifications,

(3) difficulty to obtain reliable data on cause variables other than tax variables, and

(4) the reliability of the variables grouping into "causes" and "indicators" in explaining the variability of the shadow economy. 


\subsection{The Size and Development of the Shadow Economies of 145 Countries over $1999 / 2000$ to $2002 / 2003$}

Finally, the results of the size and development of the shadow economies of 145 countries are shown (and the countries are listed in alphabetical order) in table 5.4 and figures 5.4.1-5.4.3.

Table 5.4: The Size of the Shadow Economy of 145 Countries

\begin{tabular}{|c|c|c|c|c|}
\hline \multirow[b]{2}{*}{ No. } & \multirow[b]{2}{*}{ Country } & \multicolumn{3}{|c|}{$\begin{array}{l}\text { Shadow Economy (in \% of off. GDP) using } \\
\text { the DYMIMIC and Currency Demand Method }\end{array}$} \\
\hline & & $1999 / 00$ & $2001 / 02$ & $2002 / 03$ \\
\hline 1 & Albania & 33,4 & 34,6 & 35,3 \\
\hline 2 & Algeria & 34,1 & 35,0 & 35,6 \\
\hline 3 & Angola & 43,2 & 44,1 & 45,2 \\
\hline 4 & Argentina & 25,4 & 27,1 & 28,9 \\
\hline 5 & Armenia & 46,3 & 47,8 & 49,1 \\
\hline 6 & Australia & 14,3 & 14,1 & 13,5 \\
\hline 7 & Austria & 9,8 & 10,6 & 10,9 \\
\hline 8 & Azerbaijan & 60,6 & 61,1 & 61,3 \\
\hline 9 & Bangladesh & 35,6 & 36,5 & 37,7 \\
\hline 10 & Belarus & 48,1 & 49,3 & 50,4 \\
\hline 11 & Belgium & 22,2 & 22,0 & 21,0 \\
\hline 12 & Benin & 47,3 & 48,2 & 49,1 \\
\hline 13 & Bhutan & 29,4 & 30,5 & 31,7 \\
\hline 14 & Bolivia & 67,1 & 68,1 & 68,3 \\
\hline 15 & Bosnia and Herzegovina & 34,1 & 35,4 & 36,7 \\
\hline 16 & Botswana & 33,4 & 33,9 & 34,6 \\
\hline 17 & Brazil & 39,8 & 40,9 & 42,3 \\
\hline 18 & Bulgaria & 36,9 & 37,1 & 38,3 \\
\hline 19 & Burkina Faso & 41,4 & 42,6 & 43,3 \\
\hline 20 & Burundi & 36,9 & 37,6 & 38,7 \\
\hline 21 & Cambodia & 50,1 & 51,3 & 52,4 \\
\hline 22 & Cameroon & 32,8 & 33,7 & 34,9 \\
\hline 23 & Canada & 16,0 & 15,8 & 15,2 \\
\hline 24 & Central African Republic & 44,3 & 45,4 & 46,1 \\
\hline 25 & Chad & 46,2 & 47,1 & 48,0 \\
\hline 26 & Chile & 19,8 & 20,3 & 20,9 \\
\hline 27 & China & 13,1 & 14,4 & 15,6 \\
\hline 28 & Colombia & 39,1 & 41,3 & 43,4 \\
\hline 29 & Congo, Dem. Rep. & 48,0 & 48,8 & 49,7 \\
\hline 30 & Congo, Rep. & 48,2 & 49,1 & 50,1 \\
\hline 31 & Costa Rica & 26,2 & 27,0 & 27,8 \\
\hline 32 & Cote d'Ivoire & 43,2 & 44,3 & 45,2 \\
\hline 33 & Croatia & 33,4 & 34,2 & 35,4 \\
\hline 34 & Czech Republic & 19,1 & 19,6 & 20,1 \\
\hline
\end{tabular}

Table 5.4: The Size of the Shadow Economy of 145 Countries - Cont. 


\begin{tabular}{|c|c|c|c|c|}
\hline No. & & $1999 / 00$ & $2001 / 02$ & $2002 / 03$ \\
\hline 35 & Denmark & 18,0 & 17,9 & 17,3 \\
\hline 36 & Dominican Republic & 32,1 & 33,4 & 34,1 \\
\hline 37 & Ecuador & 34,4 & 35,1 & 36,7 \\
\hline 38 & Egypt, Arab Rep. & 35,1 & 36,0 & 36,9 \\
\hline 39 & El Salvador & 46,3 & 47,1 & 48,3 \\
\hline 40 & Estonia & 38,4 & 39,2 & 40,1 \\
\hline 41 & Ethiopia & 40,3 & 41,4 & 42,1 \\
\hline 42 & Fiji & 33,6 & 34,3 & 35,1 \\
\hline 43 & Finland & 18,1 & 18,0 & 17,4 \\
\hline 44 & France & 15,2 & 15,0 & 14,5 \\
\hline 45 & Georgia & 67,3 & 67,6 & 68,0 \\
\hline 46 & Germany & 16,0 & 16,3 & 16,8 \\
\hline 47 & Ghana & 41,9 & 42,7 & 43,6 \\
\hline 48 & Greece & 28,7 & 28,5 & 28,2 \\
\hline 49 & Guatemala & 51,5 & 51,9 & 52,4 \\
\hline 50 & Guinea & 39,6 & 40,8 & 41,3 \\
\hline 51 & Haiti & 55,4 & 57,1 & 58,6 \\
\hline 52 & Honduras & 49,6 & 50,8 & 51,6 \\
\hline 53 & Hong Kong, China & 16,6 & 17,1 & 17,2 \\
\hline 54 & Hungary & 25,1 & 25,7 & 26,2 \\
\hline 55 & India & 23,1 & 24,2 & 25,6 \\
\hline 56 & Indonesia & 19,4 & 21,8 & 22,9 \\
\hline 57 & Iran, Islamic Rep. & 18,9 & 19,4 & 19,9 \\
\hline 58 & Ireland & 15,9 & 15,7 & 15,3 \\
\hline 59 & Israel & 21,9 & 22,8 & 23,9 \\
\hline 60 & Italy & 27,1 & 27,0 & 25,7 \\
\hline 61 & Jamaica & 36,4 & 37,8 & 38,9 \\
\hline 62 & Japan & 11,2 & 11,1 & 10,8 \\
\hline 63 & Jordan & 19,4 & 20,5 & 21,6 \\
\hline 64 & Kazakhstan & 43,2 & 44,1 & 45,2 \\
\hline 65 & Kenya & 34,3 & 35,1 & 36,0 \\
\hline 66 & Kiribati & 34,1 & 35,0 & 35,3 \\
\hline 67 & Korea, Rep. & 27,5 & 28,1 & 28,8 \\
\hline 68 & Kuwait & 20,1 & 20,7 & 21,6 \\
\hline 69 & Kyrgyz Republic & 39,8 & 40,3 & 41,2 \\
\hline 70 & Lao PDR & 30,6 & 31,9 & 33,4 \\
\hline 71 & Latvia & 39,9 & 40,7 & 41,3 \\
\hline 72 & Lebanon & 34,1 & 35,6 & 36,2 \\
\hline 73 & Lesotho & 31,3 & 32,4 & 33,3 \\
\hline 74 & Lithuania & 30,3 & 31,4 & 32,6 \\
\hline 75 & Macedonia, FYR & 34,1 & 35,1 & 36,3 \\
\hline 76 & Madagascar & 39,6 & 40,4 & 41,6 \\
\hline 77 & Malawi & 40,3 & 41,2 & 42,1 \\
\hline 78 & Malaysia & 31,1 & 31,6 & 32,2 \\
\hline 79 & Maldives & 30,3 & 31,4 & 32,0 \\
\hline 80 & Mali & 42,3 & 43,9 & 44,7 \\
\hline 81 & Marshall Islands & 28,1 & 29,0 & 29,6 \\
\hline 82 & Mauritania & 36,1 & 37,2 & 38,0 \\
\hline 83 & Mexico & 30,1 & 31,8 & 33,2 \\
\hline 84 & Micronesia, Fed. Sts. & 31,3 & 32,1 & 33,2 \\
\hline 85 & Moldova & 45,1 & 47,3 & 49,4 \\
\hline
\end{tabular}

Table 5.4: The Size of the Shadow Economy of 145 Countries - Cont. 


\begin{tabular}{|c|c|c|c|c|}
\hline \multirow[b]{2}{*}{86} & Country & \multicolumn{3}{|c|}{$\begin{array}{l}\text { Shadow Economy (in \% of off. GDP) using } \\
\text { the DYMIMIC and Currency Demand Method }\end{array}$} \\
\hline & Mongolia & 18,4 & 19,6 & 20,4 \\
\hline 87 & Morocco & 36,4 & 37,1 & 37,9 \\
\hline 88 & Mozambique & 40,3 & 41,3 & 42,4 \\
\hline 89 & Namibia & 31,4 & 32,6 & 33,4 \\
\hline 90 & Nepal & 38,4 & 39,7 & 40,8 \\
\hline 91 & Netherlands & 13,1 & 13,0 & 12,6 \\
\hline 92 & New Zealand & 12,8 & 12,6 & 12,3 \\
\hline 93 & Nicaragua & 45,2 & 46,9 & 48,2 \\
\hline 94 & Niger & 41,9 & 42,6 & 43,8 \\
\hline 95 & Nigeria & 57,9 & 58,6 & 59,4 \\
\hline 96 & Norway & 19,1 & 19,0 & 18,4 \\
\hline 97 & Oman & 18,9 & 19,4 & 19,8 \\
\hline 98 & Pakistan & 36,8 & 37,9 & 38,7 \\
\hline 99 & Palau & 28,4 & 29,2 & 30,0 \\
\hline 100 & Panama & 64,1 & 65,1 & 65,3 \\
\hline 101 & Papua New Guinea & 36,1 & 37,3 & 38,6 \\
\hline 102 & Paraguay & 27,4 & 29,2 & 31,4 \\
\hline 103 & Peru & 59,9 & 60,3 & 60,9 \\
\hline 104 & Philippines & 43,4 & 44,5 & 45,6 \\
\hline 105 & Poland & 27,6 & 28,2 & 28,9 \\
\hline 106 & Portugal & 22,7 & 22,5 & 21,9 \\
\hline 107 & Puerto Rico & 28,4 & 29,4 & 30,7 \\
\hline 108 & Romania & 34,4 & 36,1 & 37,4 \\
\hline 109 & Russian Federation & 46,1 & 47,5 & 48,7 \\
\hline 110 & Rwanda & 40,3 & 41,4 & 42,2 \\
\hline 111 & Samoa & 31,4 & 32,6 & 33,5 \\
\hline 112 & Saudi Arabia & 18,4 & 19,1 & 19,7 \\
\hline 113 & Senegal & 45,1 & 46,8 & 47,5 \\
\hline 114 & Serbia and Montenegro & 36,4 & 37,3 & 39,1 \\
\hline 115 & Sierra Leone & 41,7 & 42,8 & 43,9 \\
\hline 116 & Singapore & 13,1 & 13,4 & 13,7 \\
\hline 117 & Slovak Republic & 18,9 & 19,3 & 20,2 \\
\hline 118 & Slovenia & 27,1 & 28,3 & 29,4 \\
\hline 119 & Solomon Islands & 33,4 & 34,5 & 35,3 \\
\hline 120 & South Africa & 28,4 & 29,1 & 29,5 \\
\hline 121 & Spain & 22,7 & 22,5 & 22,0 \\
\hline 122 & Sri Lanka & 44,6 & 45,9 & 47,2 \\
\hline 123 & Sweden & 19,2 & 19,1 & 18,3 \\
\hline 124 & Switzerland & 8,6 & 9,4 & 9,4 \\
\hline 125 & Syrian Arab Republic & 19,3 & 20,4 & 21,6 \\
\hline 126 & Taiwan, China & 25,4 & 26,6 & 27,7 \\
\hline 127 & Tanzania & 58,3 & 59,4 & 60,2 \\
\hline 128 & Thailand & 52,6 & 53,4 & 54,1 \\
\hline 129 & Togo & 35,1 & 39,2 & 40,4 \\
\hline 130 & Tonga & 35,1 & 36,3 & 37,4 \\
\hline 131 & Tunisia & 38,4 & 39,1 & 39,9 \\
\hline 132 & Turkey & 32,1 & 33,2 & 34,3 \\
\hline 133 & Uganda & 43,1 & 44,6 & 45,4 \\
\hline 134 & Ukraine & 52,2 & 53,6 & 54,7 \\
\hline 135 & United Arab Emirates & 26,4 & 27,1 & 27,8 \\
\hline 136 & United Kingdom & 12,7 & 12,5 & 12,2 \\
\hline
\end{tabular}

Table 5.4: The Size of the Shadow Economy of 145 Countries - Cont. 


\begin{tabular}{|c|c|c|c|c|}
\hline \multirow[b]{2}{*}{137} & Country & \multicolumn{3}{|c|}{$\begin{array}{l}\text { Shadow Economy (in \% of off. GDP) using } \\
\text { the DYMIMIC and Currency Demand Method }\end{array}$} \\
\hline & United States & 8,7 & 8,7 & 8,4 \\
\hline 138 & Uruguay & 51,1 & 51,4 & 51,9 \\
\hline 139 & Uzbekistan & 34,1 & 35,7 & 37,2 \\
\hline 140 & Vanuatu & 30,9 & 31,7 & 32,5 \\
\hline 141 & Venezuela, RB & 33,6 & 35,1 & 36,7 \\
\hline 142 & Vietnam & 15,6 & 16,9 & 17,9 \\
\hline 143 & Yemen, Rep. & 27,4 & 28,4 & 29,1 \\
\hline 144 & Zambia & 48,9 & 49,7 & 50,8 \\
\hline 145 & Zimbabwe & 59,4 & 61 & 63,2 \\
\hline \multicolumn{2}{|c|}{ Unweighted Average } & 33,6 & 34,5 & 35,2 \\
\hline
\end{tabular}




\section{References}

Ahumada, Hildegard, Alvaredo, Facundo, Canavese Alfredo. and Paula. Canavese (2004): The demand for currency approach and the size of the shadow economy: A critical assessment, Discussion Paper, Delta Ecole. Normale Superieure, Paris.

Adam, Markus, C. and Victor Ginsburgh, (1985), The effects of irregular markets on macroeconomic policy: Some estimates for Belgium, European Economic Review, 29/1, pp. 15-33.

Aigner, Dennis; Schneider, Friedrich and Damayanti Ghosh (1988): Me and my shadow: estimating the size of the US hidden economy from time series data, in W. A. Barnett; E. R. Berndt and H. White (eds.): Dynamic econometric modeling, Cambridge (Mass.): Cambridge University Press, pp. 224-243.

Alexeev, Michael and Pyle, William (2003): A note on measuring the unofficial economy in the former Soviet Republics, Economics of Transition, 11/1, p.1-23.

Alm, James, Martinez-Vazquez, Jorge and Friedrich Schneider (2004), 'Sizing the problem of the hard-to-tax', Working Paper, Georgia State University: USA.

Andreoni, James; Erard, Brian, and Jonathan Feinstein (1998): Tax compliance. Journal of Economic Literature, 36, pp. 818-860.

Asea, Patrick K. (1996): The informal sector: baby or bath water? Carnegie-Rochester Conference Series on Public Policy 45., pp. 163-171.

Bajada Christopher (2002): Australia's Cash Economy: A Troubling Issue for Policy Makers. Aldershort (Great Britain), Ashgate Publishing Company.

Bajada, Christopher and Friedrich Schneider (2003): The size and development of the shadow economies in the Asia-Pacific, Discussion Paper, Department of Economics, University of Linz, Austria, forthcoming in the Asian Pacific Economic Journal, 2005.

Barro, Robert. J. and Sala-i-Martin, Xavier. (1995), ‘Economic Growth’, McGraw-Hill: USA.

Belev, Boyan (2003): The informal economy in the EU Accession Countries: Size, scope, trends and challenges to the process of EU enlargement, Center for Study of Democracy, Sofia.

Bhattacharyya, D.K. (1999): On the economic rationale of estimating the hidden economy, The Economic Journal 109/456, pp. 348-359.

Blades, Derek (1982): “The hidden economy and the national accounts", OECD (Occasional Studies), Paris, pp. 28-44.

Boeschoten, Werner C. and Marcel M.G. Fase (1984): The Volume of Payments and the Informal Economy in the Netherlands 1965-1982, M. Nijhoff, Dordrecht.

Brehm, J.W. (1966): A Theory of Psychological Reactance. New York (Academic Press).

Brehm, J.W. (1972): Responses to Loss of Freedom. A Theory of Psychological Reactance. Morristown (General Learning Press).

Cagan, Phillip (1958): "The demand for currency relative to the total money supply," Journal of Political Economy, 66:3, pp. 302-328.

Chatterjee, S.; Chaudhury K. and F. Schneider (2003): The size and development of the Indian shadow economy and a comparison with other 18 Asian countries: An empirical investigation, Discussion Paper, Department of Economics, University of Linz, Austria.

Clotefelter, Charles T. (1983): Tax evasion and tax rates: An analysis of individual return, Review of Economic Statistics, 65/3, pp. 363-373.

Contini, Bruno (1981): Labor market segmentation and the development of the parallel economy - the Italian experience, Oxford Economic Papers, 33/4, pp. 401-12.

Dallago, Bruno (1990): The irregular economy: The "underground economy" and the "black labour market", Dartmouth (U.K.), Publishing Company.

Del'Anno, Roberto (2003): Estimating the shadow economy in Italy: A structural equation approach, Discussion Paper, Department of Economics and Statistics, University of Salerno.

Del'Anno, Roberto and Friedrich Schneider (2004): The shadow economy of Italy and other OECD countries: What do we know?, Linz: University of Linz, Department of Economics, Discussion Paper, forthcoming in Journal of Public Finance and Public Choice, 2005.

Del Boca, Daniela. (1981): Parallel economy and allocation of time, Micros (Quarterly Journal of Microeconomics), 4/2, pp. 13-18. 
Del Boca, Daniela and Francesco Forte (1982): Recent empirical surveys and theoretical interpretations of the parallel economy in Italy; Tanzi, Vito (1982) (ed.): The underground economy in the United States and abroad, Lexington (Mass.), Lexington, pp. 160-178.

Feige, Edgar L. (1986): A re-examination of the "Underground Economy" in the United States. IMF Staff Papers, 33/ 4, pp. 768-781.

Feige, Edgar L. (1989) (ed.): The Underground Economies. Tax Evasion and Information Distortion. Cambridge, New York, Melbourne, Cambridge University Press.

Feige, Edgar L. (1994): The underground economy and the currency enigma, Supplement to Public Finance/ Finances Publiques, 49, pp. 119-136.

Feige, Edgar L. (1996): Overseas holdings of U.S. currency and the underground economy, in: Pozo, Susan (ed.): Exploring the Underground Economy. Kalamazoo, Michigan, pp. 5-62.

Fleming, M.H.; Roman, J. and G. Farrel (2000): The shadow economy, Journal of International Affairs, Spring 2000, No. 53/2, pp.64-89.

Franz, A. (1983): Wie groß ist die "schwarze" Wirtschaft?, Mitteilungsblatt der Österreichischen Statistischen Gesellschaft, 49/1, pp. 1-6.

Frey, Bruno S. and Hannelore Weck (1983a): "Bureaucracy and the Shadow Economy: A Macro-Approach", in Horst Hanusch (ed.): Anatomy of Government Deficiencies. Berlin: Springer, pp. 89-109.

Frey, Bruno S. and Hannelore Weck (1983b): "Estimating the Shadow Economy: A 'Naive' Approach," Oxford Economic Papers, 35, pp. 23-44.

Frey, Bruno S. and Hannelore Weck-Hannemann (1984): The hidden economy as an "unobserved" variable, European Economic Review, 26/1, pp. 33-53.

Frey, Bruno S. and Werner Pommerehne (1984): The hidden economy: State and prospect for measurement, Review of Income and Wealth, 30/1, pp. 1-23.

Frey, Bruno S., Weck Hannelore and Werner W. Pommerehne (1982): Has the shadow economy grown in Germany? An exploratory study, Weltwirtschaftliches Archiv, 118/4, pp. 499-524.

Friedman, E., Johnson, S., Kaufmann, D. and Zoido-Labton, P. (2000): Dodging the grabbing hand: The determinants of unofficial activity in 69 countries, Journal of Public Economics, 76/4, pp.459-493.

Garcia, Gillian (1978): “The currency ratio and the subterranean economy,” Financial Analysts Journal, 69:1, pp. 64-66.

Gerxhani, Klarita (2003): The informal sector in developed and less-developed countries: A literature survey, Public Choice, 114/3-4, pp.295-318.

Giles, David, E.A. (1997a): Causality between the measured and underground economies in New Zealand, Applied Economic Letters 4, pp.63-67.

Giles, David, E.A. (1997b): Testing the asymmetry in the measured and underground business cycles in New Zealand, Economic Record 71/1, pp.225-232.

Giles, David, E.A. (1999a): Measuring the hidden economy: Implications for econometric modelling, The Economic Journal, 109/456, pp.370-380.

Giles, David, E.A. (1999b): Modelling the hidden economy in the tax-gap in New Zealand, Empirical Economics 24/4, pp.621-640.

Giles, David, E.A. (1999c): The rise and fall of the New Zealand underground economy: are the reasons symmetric?, Applied Economic Letters 6, pp. 185-189.

Giles, David, E.A. and Lindsay M. Tedds (2002): Taxes and the Canadian Underground Economy, Canadian Tax Paper No. 106, Canadian Tax Foundation, Toronto/Ontario.

Giles, David, E.A., Tedds, Lindsay, M. and Werkneh, Gugsa (2002): The Canadian underground and measured economies, Applied Economics, 34/4, pp.2347-2352.

Gutmann, Pierre M. (1977): “The subterranean economy,” Financial Analysts Journal, 34:1, pp. $24-27$.

Helberger, Claus and Hans Knepel (1988): "How big is the shadow economy? A re-analysis of the unobservedvariable approach of B. S. Frey and H. Weck-Hannemann”, European Economic Journal, 32, pp. 965-76.

Hill, Roderick and Muhammed Kabir (1996): Tax rates, the tax mix, and the growth of the underground economy in Canada: What can we infer? Canadian Tax Journal/ Revue Fiscale Canadienne, 44/ 6, pp. $1552-1583$.

IRS (1979): Estimates of Income Unreported on Individual Tax Reforms, Washington D.C.: Internal revenue service, U.S. Department of the Treasury.

IRS (1983): Income Tax Compliance Research: Estimates for 1973-81, Washington D.C.: Internal revenue service, U.S. Department of the Treasury. 
Isachsen, Arne J. and Steinar Strom (1985): The size and growth of the hidden economy in Norway, Review of Income and Wealth, 31/1, pp. 21-38.

Isachsen, Arne J.; Klovland, Jan and Steinar Strom (1982): The hidden economy in Norway, in: Tanzi Vito (ed.): The underground economy in the United States and Abroad, Heath, Lexington, pp. 209-231.

Johnson, Simon; Kaufmann, Daniel; and Andrei Shleifer (1997): The unofficial economy in transition, Brookings Papers on Economic Activity, Fall, Washington D.C.

Johnson, Simon; Kaufmann, Daniel and Pablo Zoido-Lobatón (1998a): Regulatory discretion and the unofficial economy. The American Economic Review, 88/ 2, pp. 387-392.

Johnson, Simon; Kaufmann, Daniel and Pablo Zoido-Lobatón (1998b): Corruption, public finances and the unofficial economy. Washington, D.C.: The World Bank, discussion paper.

Karmann, Alexander (1986), Monetäre Ansätze zur Erfassung der Schattenwirtschaft: Ein Vergleich verschiedener Messansätze, Kredit und Kapitel 19/3, pp.233-247.

Karmann, Alexander (1990), Schattenwirtschaft und ihre Ursachen: Eine empirische Analyse zur Schwarzwirtschaft und Selbstversorgung in der Bundesrepublik Deutschland, Zeitschrift für Wirtschaftsund Sozialwissenschaften (ZWS) 110/3, 1990, pp.185-206.

Kaufmann, Daniel and Kaliberda, Aleksander (1996), Integrating the unofficial economy into the dynamics of post socialist economies: A framework of analyses and evidence, in: B. Kaminski (ed.), Economic Transition in Russia and the New States of Eurasia, London: M.E. Sharpe, pp.81-120.

Kirchgaessner, Gebhard (1983): Size and development of the West German shadow economy, 1955-1980, Zeitschrift für die gesamte Staatswissenschaft, 139/2, pp. 197-214.

Kirchgaessner, Gebhard (1984): Verfahren zur Erfassung des in der Schattenwirtschaft erarbeiteten Sozialprodukts, Allgemeines Statistisches Archiv, 68/4, pp. 378-405.

Kirchler, E.; Maciejovsky, B. and F. Schneider (2002): Everyday representations of tax avoidance, tax evasion and tax flight: Do legal differences matter?, Economic Psychology, 8/3, pp.1-19.

Klovland, Jan (1984): "Tax evasion and the demand for currency in Norway and Sweden: Is there a hidden relationship?” Scandinavian Journal of Economics, 86:4, pp. 423-39.

Lackó Mária (1996): Hidden economy in East-European countries in international comparison, Laxenburg: International Institute for Applied Systems Analysis (IIASA), working paper.

Lackó Mária (1998): The hidden economies of Visegrad countries in international comparison: A household electricity approach, In: Halpern, L. and Wyplosz, Ch. (eds.), Hungary: Towards a market economy, Cambridge (Mass.): Cambridge University Press, p.128-152.

Lackó Mária (1999): Hidden economy an unknown quantitiy? Comparative analyses of hidden economies in transition countries in 1989-95, Working paper 9905, Department of Economics, University of Linz, Austria.

Lackó Mária (2000), Hidden Economy - An unknown quantity: Comparative analysis of hidden economics in Transition countries 1989-95, Economics of Transition 8/1, pp.117-149.

Langfeldt, Enno (1984): The unobserved economy in the Federal Republic of Germany, in: Feige, Edgar L. (ed.): The unobserved economy, Cambridge University Press., pp. 236-260.

Lippert, Owen and Michael Walker (eds.) (1997): The Underground Economy: Global Evidences of its Size and Impact, Vancouver, B.C.: The Frazer Institute.

Lizzeri, C. (1979): Mezzogiorno in controluce. Enel, Naples.

Loayza, N. V. (1996): The economics of the informal sector: a simple model and some empirical evidence from Latin America. Carnegie-Rochester Conference Series on Public Policy 45, pp. 129-162.

MacAfee, Kerrick (1980): A Glimpse of the hidden economy in the national accounts, Economic Trends, 136, pp. 81-87.

Mauleon, Ignacio (1998): Quantitative estimation of the Spanish underground economy, Discussion paper, Department of Economics and History, University of Salamanka, Salamanka, Spain.

Mogensen, Gunnar V.; Kvist, Hans K.; Körmendi, Eszter and Soren Pedersen (1995): The shadow economy in Denmark 1994: Measurement and results, Study no. 3, Copenhagen: The Rockwool Foundation Research Unit.

Morris, B. (1993), Editorial Statement. International Economic Insides, IV, International Statistical Yearbook, Budapest.

Mummert, Annette and Friedrich Schneider (2001): The German shadow economy: Parted in a united Germany?, Finanzarchiv, 58/3, pp.260-285. 
Neck, Reinhard, Hofreither, Markus and Friedrich Schneider (1989): The consequences of progressive income taxation for the shadow economy: Some theoretical considerations, in Boes, Dieter and Felderer, Bernhard (eds.), The political economy of progressive taxation, Heidelberg: Springer publishing company, pp. 149176.

O’Higgins, Michael (1989): Assessing the underground economy in the United Kingdom, in: Feige, E.L. (ed.): The underground economies: tax evasion and information distortion, Cambridge: Cambridge University Press, pp. 175-195.

O’Neill, David M. (1983): Growth of the underground economy 1950-81: Some evidence from the current population survey, Study for the Joint Economic Committee, U.S. Congress, Joint Committee Print 98-122, U.S. Gov. Printing Office, Washington.

Park, T. (1979): Reconciliation between personal income and taxable income, pp. 1947-77, mimeo, Washington D.C.: Bureau of Economic Analysis.

Pelzmann, Linde (1988): Wirtschaftspsychologie. Arbeitslosenforschung, Schattenwirtschaft, Steuerpsychologie. Wien, New York (Springer).

Pedersen, Soren (2003): The Shadow Economy in Germany, Great Britain and Scandinavia: A Measurement Based on Questionnaire Service, Study No. 10, The Rockwoll Foundation Research Unit, Copenhagen.

Petersen, H.-G.(1982): Size of the public sector, economic growth and the informal economy: Development trends in the Federal Republic of Germany, Review of Income and Wealth, 28/2, pp. 191-215.

Pissarides, C. and Weber, G. (1988): An expenditure - based estimate of Britain's black economy, CLE working paper no. 104, London.

Portes, Alejandro (1996): The informal economy, in: Pozo, Susan (ed.): Exploring the underground economy. Kalamazoo, Michigan, pp. 147-165.

Pozo, Susan (ed.) (1996): Exploring the Underground Economy: Studies of Illegal and Unreported Activity, Michigan: W.E. Upjohn, Institute for Employment Research.

Quirk, Peter, J., (1996), Macroeconomic implications of money laundering, IMF working paper WP/96/66, Washington, D.C.

Rogoff, Kenneth, (1998), Blessing or Curse? Foreign and underground demand for euro notes, Economic policy: The European Forum 26, pp. 261-304.

Schneider, Friedrich (1986): Estimating the size of the Danish shadow economy using the currency demand approach: An attempt, The Scandinavian Journal of Economics, 88/4, pp. 643-668.

Schneider, Friedrich (1994a): Measuring the size and development of the shadow economy. Can the causes be found and the obstacles be overcome? in: Brandstaetter, Hermann, and Güth, Werner (eds.): Essays on Economic Psychology, Berlin, Heidelberg, Springer Publishing Company, pp. 193-212.

Schneider, Friedrich (1994b): Can the shadow economy be reduced through major tax reforms? An empirical investigation for Austria, Supplement to Public Finance/ Finances Publiques, 49, pp. 137-152.

Schneider, Friedrich (1997): The shadow economies of Western Europe, Journal of the Institute of Economic Affairs, 17/3, pp. 42-48.

Schneider, Friedrich (1998a): Further empirical results of the size of the shadow economy of 17 OECD-countries over time, Paper to be presented at the 54. Congress of the IIPF Cordowa, Argentina and discussion paper, Department of Economics, University of Linz, Linz, Austria.

Schneider, Friedrich (1998b): Stellt das Anwachsen der Schwarzarbeit eine wirtschaftspolitische Herausforderung dar? Einige Gedanken aus volkswirtschaftlicher Sicht. Linz, Mitteilungen des Instituts für angewandte Wirtschaftsforschung (IAW), I/98, S. 4-13.

Schneider, Friedrich (2000): The increase of the size of the shadow economy of 18 OECD-Countries: Some preliminary explanations, Paper presented at the Annual Public Choice Meeting, March 10-12, 2000, Charleston, S.C.

Schneider, Friedrich (2003): The shadow economy, in: Charles K. Rowley and Friedrich Schneider (eds.), Encyclopedia of Public Choice, Kluwer Academic Publishers, Dordrecht.

Schneider, Friedrich (2005): Shadow Economies around the World: What do we really know?, forthcoming European Journal of Political Economy, 2005.

Schneider, Friedrich, Markus F. Hofreither and Reinhard Neck, (1989), The consequences of a changing shadow economy for the official economy: Some empirical results for Austria, in Boes, Dieter and Bernhard Felderer (eds.), The political economy of progressive taxation, Heidelberg: Springer publishing company, pp. 181-211.

Schneider, Friedrich and Dominik Enste (2000): Shadow economies: Size, causes, and consequences, The Journal of Economic Literature, 38/1, pp. 77-114. 
Schneider, F., Enste D. (2002). The Shadow Economy: Theoretical Approaches, Empirical Studies, and Political Implications, Cambridge (UK): Cambridge University Press.

Simon, C.B. and A.G. Witte (1982): Beating the system: The underground economy, Boston, (Mas.): Urban House.

Smith, J.D (1985): Market motives in the informal economy, in: Gaertner, W. and Wenig, A. (eds.): The economics of the shadow economy, Heidelberg: Springer Publishing Company, pp. 161-177.

Smith, Philip (1994): Assessing the size of the underground economy: The statistics Canada perspectives, Canadian Economic Observer, Catalogue No.: 11-010, 3.16-33, at 3.18.Spiro, Peter S. (1993): "Evidence of a Post-GST Increase in the Underground Economy;" Canadian Tax Journal/ Revue Fiscale Canadienne, , 41:2, pp. 247-258.

Tanzi, Vito (1980): "The underground economy in the United States: Estimates and implications," Banca Nazionale del Lavoro, 135:4, pp. 427-453.

Tanzi, Vito (1982) (ed.): The Underground Economy in the United States and Abroad, Lexington (Mass.), Lexington.

Tanzi, Vito (1982): A second (and more skeptical) look at the underground economy in the United States; in: Tanzi, Vito (1982) (ed.): The underground economy in the United States and abroad, Lexington (Mass.), Lexington, pp. 38-56.

Tanzi, Vito (1983): "The underground economy in the United States: Annual estimates, 1930-1980," IMF-Staff Papers, 30:2, pp. 283-305.

Tanzi, Vito (1986): The underground economy in the United States, Reply to comments by Feige, Thomas, and Zilberfarb. IMF - Staff Papers, 33/ 4, pp. 799-811.

Tanzi, Vito (1999): Uses and abuses of estimates of the underground economy, The Economic Journal 109/456, pp.338-340.

Thomas, Jim J. (1986): The underground economy in the United States: A comment on Tanzi, IMF-Staff Papers, Vol. 33, No. 4, pp. 782-789.

Thomas, Jim J. (1992): Informal Economic Activity, LSE, Handbooks in Economics, London: Harvester Wheatsheaf.

Thomas, Jim J. (1999): Quantifying the black economy: 'Measurement without Theory' Yet Again?, The Economic Journal 109/456, pp. 381-389.

Weck, Hannelore (1983): Schattenwirtschaft: Eine Möglichkeit zur Einschränkung der öffentlichen Verwaltung? Eine ökonomische Analyze, Bern-Frankfurt.

Williams, Colin C. and Jan Windebank (1995): "Black market work in the European Community: Peripheral work for peripheral localities?", International Journal of Urban and Regional Research, 19/1, pp. 23-39.

Witte, A.D. (1987): The nature and extend of unreported activity: A survey concentrating on a recent USresearch, in: Alessandrini, S. and Dallago, B. (eds.): The Unofficial Economy: Consequences and perspectives in different economic systems, Gower: Aldershot.

Zilberfarb, Ben-Zion (1986): Estimates of the underground economy in the United States, 1930-80. IMF-Staff Papers, 33/4, pp. 790-798. 